\title{
Extension parallel to the rift zone during segmented fault growth: application to the evolution of the NE Atlantic
}

\author{
Alodie Bubeck ${ }^{1}$, Richard J. Walker ${ }^{1}$, Jonathan Imber ${ }^{2}$, Robert E. Holdsworth ${ }^{2}$, Christopher J. MacLeod ${ }^{3}$, and \\ David A. Holwell ${ }^{1}$ \\ ${ }^{1}$ Department of Geology, University of Leicester, Leicester, LE1 7RH, UK \\ ${ }^{2}$ Department of Earth Sciences, Durham University, Durham, DH1 3LE, UK \\ ${ }^{3}$ Department of Earth and Ocean Sciences, Cardiff University, Cardiff, CF10 3AT, UK
}

Correspondence to: Alodie Bubeck (ab753@le.ac.uk)

Received: 21 August 2017 - Discussion started: 24 August 2017

Revised: 15 October 2017 - Accepted: 17 October 2017 - Published: 22 November 2017

\begin{abstract}
The mechanical interaction of propagating normal faults is known to influence the linkage geometry of firstorder faults, and the development of second-order faults and fractures, which transfer displacement within relay zones. Here we use natural examples of growth faults from two active volcanic rift zones (Koa'e, island of Hawai ' $i$, and Krafla, northern Iceland) to illustrate the importance of horizontalplane extension (heave) gradients, and associated vertical axis rotations, in evolving continental rift systems. Secondorder extension and extensional-shear faults within the relay zones variably resolve components of regional extension, and components of extension and/or shortening parallel to the rift zone, to accommodate the inherently three-dimensional (3D) strains associated with relay zone development and rotation. Such a configuration involves volume increase, which is accommodated at the surface by open fractures; in the subsurface this may be accommodated by veins or dikes oriented obliquely and normal to the rift axis. To consider the scalability of the effects of relay zone rotations, we compare the geometry and kinematics of fault and fracture sets in the Koa'e and Krafla rift zones with data from exhumed contemporaneous fault and dike systems developed within a $>5 \times 10^{4} \mathrm{~km}^{2}$ relay system that developed during formation of the NE Atlantic margins. Based on the findings presented here we propose a new conceptual model for the evolution of segmented continental rift basins on the NE Atlantic margins.
\end{abstract}

\section{Introduction}

The primary regional-scale segmentation of extensional terranes is controlled by the development of networks of normal fault systems and the partitioning of strain across them. Normal faults comprise multiple discontinuous, non-collinear segments, with overlaps and segment linkage forming characteristic stepping geometries on a broad range of scales (e.g. Cartwright et al., 1996; Peacock et al., 2000; Acocella et al., 2005; Long and Imber, 2011; Henstra et al., 2015). Fault growth models have been derived using natural examples and numerical, or scaled-analogue modelling techniques, in which normal faults grow through stages in which discontinuous segments interact and link across relay zones to form composite structures with fault displacement deficits initially accommodated by soft-linkage rotation and/or material folding (e.g. Trudgill and Cartwright, 1994; Gupta and Scholz, 2000; Peacock, 2002; Long and Imber, 2010).

Mechanical interaction (i.e. in which the mechanical behaviour of a fault segment is altered in the presence of another segment by the elastic interaction of their respective stress fields; see e.g. Segall and Pollard, 1980; Willemse et al., 1996) between discontinuous fault segments can have an important influence on fault system evolution, including the geometry of first-order (i.e. largest scale of observation) faults and the development and distribution of second-order (i.e. ancillary) faults and fractures within developing interfault (relay) zones. Segmentation is a feature common to all scales of faults and fault development (e.g. Walsh et al., 2003; Long and Imber, 2011) and the conservation of regional strain across networks of discontinuous segments has 
been well established (e.g. Peacock and Sanderson, 1991; Peacock, 2002; Fossen and Rotevatn, 2016). Normal fault displacement is typically considered with emphasis on the vertical motion (fault throw), which can be measured using offset bedding, either in the field, laboratory, or using highresolution seismic imaging. In horizontally layered materials, displacement (throw) gradients on adjacent normal faults are commonly accommodated by relay structures (e.g. Peacock and Sanderson, 1991; Childs et al., 1995; Long and Imber, 2010), requiring horizontal axis bending of the host layering (Fig. 1). The bounding faults of a relay zone also exhibit opposing horizontal displacement (heave) gradients, which requires a component of vertical axis rotation to maintain the connection between the hanging wall and footwall (e.g. Ferrill and Morris, 2001). Few studies have addressed this rotational strain (see e.g. Koehn et al., 2008) and the resulting horizontal extension profile between faults or the potential for non-plane stresses and strains within the relay zone. Unlike horizontal axis rotation, it cannot be accommodated by layer-parallel or flexural slip between layers (unless layering is vertical) and thus requires the material to bend or stretch within the layer plane.

We present field examples of growth faults from two active volcanic rift zone segments - the Koa'e (island of Hawai'i) and Krafla (northern Iceland) fault systems - to demonstrate the inherently three-dimensional (3-D) strains associated with extensional strain gradients within evolving relay zones. The Koa'e fault system represents an early stage rift that connects the East and Southwest rift zones of Kīlauea Volcano to produce a continuous zone of extension that facilitates southward flank motion. The Krafla fissure swarm represents a well-established and highly extended portion of the Neovolcanic Zone of Iceland: a subaerially exposed segment of the NE Atlantic spreading ridge. Faults in both study areas are interpreted to be upward-propagating (e.g. Tentler, 2005; Martel and Langley, 2006) syn-volcanic growth faults (e.g. Macdonald et al., 1996; Dauteuil et al., 2001; Holland et al., 2006). The two case studies represent early and advanced stages in normal fault linkage during rifting.

In both case studies the expression of surface strains records minor $(\leq 20 \%)$ extension, in which respect they can be considered analogous to the surface expression of evolving extensional systems. The aim of this paper is to demonstrate the importance of displacement variation as a function of fault heave, rather than throw, and highlight the potential for the development of non-plane strains and volume change on the scale of the intervening relay zones. We consider the potential for such 3-D strains to form a viable alternative model to explain complex fault sets in laterally propagating rift systems: here we contrast structures in the Koa'e and Krafla regions to upper crustal (e.g. $\sim 1-6 \mathrm{~km}$ depth) structures of a scale that is at least 1 order of magnitude greater, developed along the NE Atlantic margins. For comparison, new and existing kinematic and geometric data are presented for Kangerlussuaq (east Greenland) and the Faroe Islands
(European) portions of the NE Atlantic margins. Based on these examples, we suggest a new conceptual model for the evolution of segmented continental rift basins, with specific reference to the NE Atlantic margin.

\section{Background: displacement transfer and relay zones in segmented normal fault systems}

Two-dimensional analyses of the stresses surrounding en échelon faults and dikes have demonstrated that mechanical interaction of opposing elastic stress fields produce areas of highly perturbed stress, which exert a control on the growth, slip distribution, and geometry of faults (e.g. Segall and Pollard, 1980; Sempere and Macdonald, 1986; Cowie and Scholz, 1992; Crider and Pollard, 1998). To maintain the extensional strain across the fault system as a whole (i.e. representing a fully linked, mature system), the volume ahead of the fault tips is required to accommodate the opposing along-strike displacement gradients on the first-order bounding fault structures. This may be accommodated in this interfault region, or relay zone, through components of elastic and inelastic strain (e.g. Peacock and Sanderson, 1991, 1994; Childs et al., 1995; Long and Imber, 2010), and depending on the degree of overlap and separation of individual segments, may lead to different styles of deformation (e.g. Tentler and Acocella, 2010; Long and Imber, 2011; Childs et al., 2017) (Fig. 1a, b).

Using scaled-analogue models, Tentler and Acocella (2010) showed that a large underlap (relative to fracture length) between fracture segments produces elongated relay zones with new linking fractures opening ahead of the tips, striking subparallel to the bounding fractures (Fig. 1d(i)). Decreasing the underlap of the bounding fractures (Fig. 1d(iiiv)) results in the growth of open fractures in the relay zones that strike at increasingly higher angles to the main structures. The propagation of these high-angle fractures generates a local component of extension, and volume increase, in a direction parallel or at low angles to the strike of the bounding fractures. At the same time, the component of extension orthogonal to the bounding structures decreases. At larger overlap geometries (Fig. 1d(v)), linking fractures strike at a lower angle, resulting in a reduction of the local component of bounding fracture-parallel extension and an increase in the fracture-normal component. The model configurations of Tentler and Acocella (2010) represent single stages of propagation and linkage, rather than the full progression. In nature, however, the process should graduate through some or all of these stages, as the bounding structures propagate toward each other and link, subjecting the relay zone to distortions as a function of the changing fault cut-off line lengths associated with slip accumulation (Fig. 1c, d).

It is typical to consider the distortions associated with normal fault displacement in terms of the vertical motion: the throw (e.g. Fig. 1d). This is perhaps due to the association 

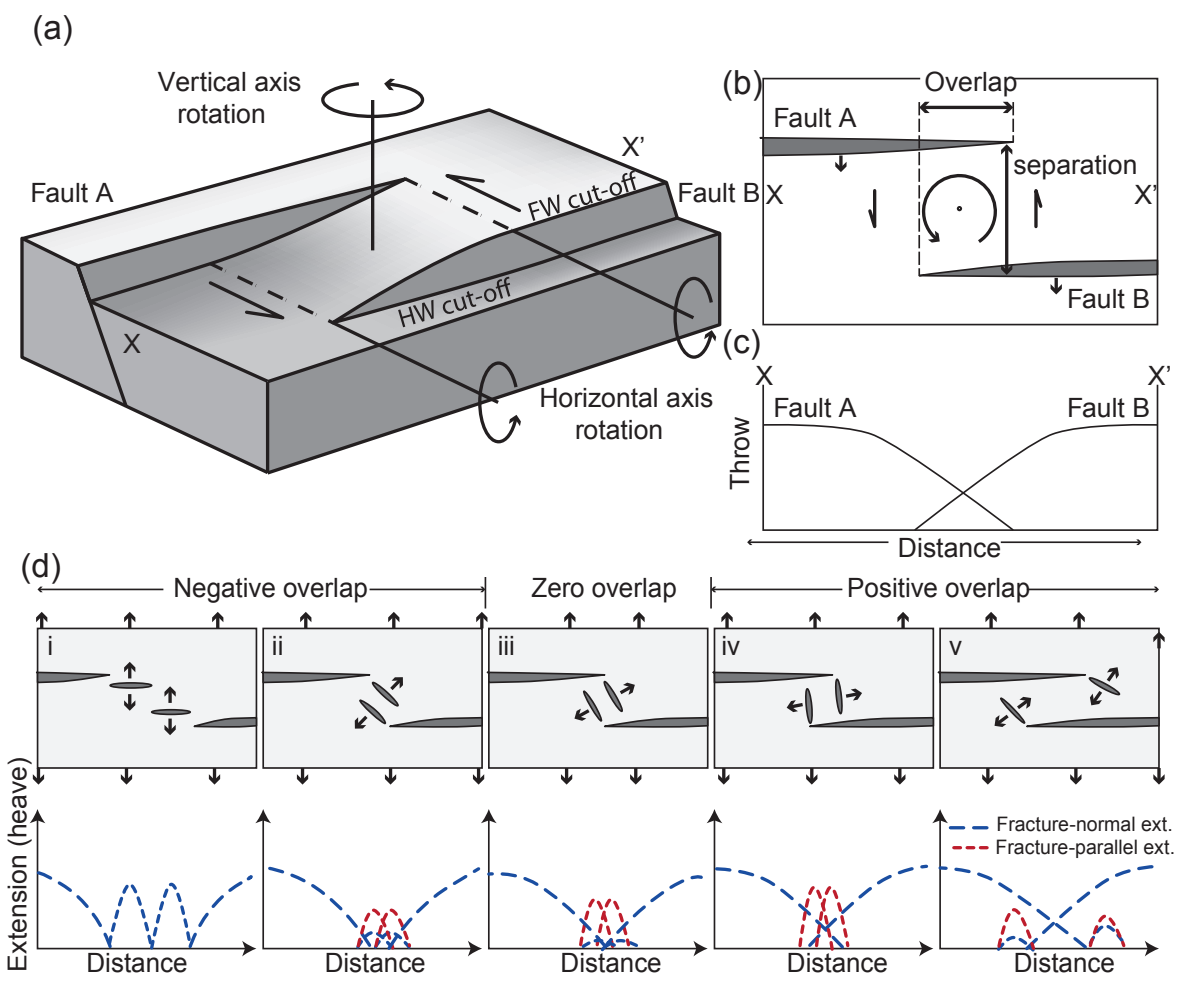

(e) Left-stepping: clockwise vertical axis rotation Right-stepping: anticlockwise vertical axis rotation
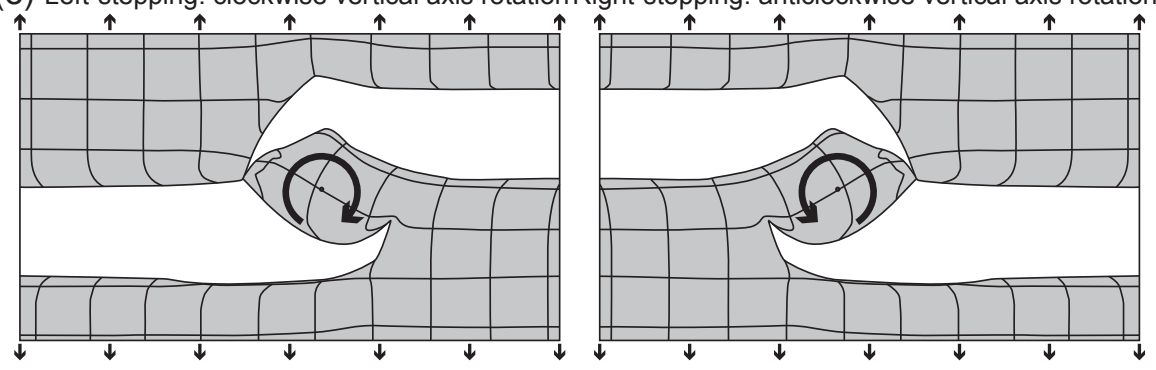

Figure 1. (a) Schematic diagram illustrating a relay zone between two normal faults (after Ferrill and Morris, 2001) showing the location of the footwall (FW) and hanging wall (HW) cut-off lines. (b) Map view of the block model in (a) showing fault overlap and separation. (c) Distance versus displacement (throw) profile for transect X-X'. (d)(i-v) Second-order fault geometries as a function of fault overlap (redrawn from Tentler and Acocella, 2010) with local and regional extension directions indicated. Graphs show schematic plots of displacement (extension or heave) length for the bounding fractures and linking geometries shown. (e) Modelled strain fields and rotation ahead of two left- and right-stepping en échelon open-mode fractures (redrawn from Tentler and Acocella, 2010).

of normal faults with gently dipping or horizontal bedding, which provides useful and abundant offset markers for measurement. There are fewer studies that have made a detailed analysis of horizontal motions - the fault heave - due to the challenges in defining them accurately. Local deficits in fault throw are identified using comparisons with a theoretical final displacement profile for a fully linked set of faults accommodating regional extension, which show a centrally located displacement maxima. Such deficits can be accommodated by the development of new synthetic faults in the relay zone, and/or by folding about a horizontal axis, producing the relay ramp. Any deficits in fault heave, however, require vertical axis rotation (Fig. 1c, e), which can be accommodated by the formation of new faults (i.e. hard-linkage; e.g. Gawthorpe and Hurst, 1993; Hus et al., 2006), or bending within the plane of bedding (i.e. soft-linkage; e.g. Childs et al., 1995; Faulds and Varga, 1998). The evolution of such structural elements will have a profound influence on the evolving tectono-stratigraphic architecture of rift basins (e.g. Lambiase and Bosworth, 1995; Sharp et al., 2000; Hus et al., 2006) as well as contributing to the sealing potential or fluid flow properties of fault zones (e.g. Morley et al., 1990; Manzocchi et al., 2010; Seebeck et al., 2014). 


\section{Methodology}

Surface-breaching normal faults in the Koa'e and Krafla fault systems cut sub-horizontal bedded lavas, which exhibit vertical columnar joint sets on a range of scales. Previous work has established that faults in layered basaltic sequences, at low confining pressures, develop as networks of extension fractures, which open along favourably oriented, pre-existing cooling joints in the lava pile, driven by tensile stresses ahead of blind normal faults (e.g. Grant and Kattenhorn, 2004; Martel and Langley, 2006). Eventual linkage of fault and fracture networks at depth results in the development of surfacebreaching, sub-vertical normal faults that exhibit components of horizontal and vertical displacement. The polygonal geometry of reactivated cooling joints allows displaced walls to be matched across the aperture of open fractures at multiple points along individual traces for (1) extension fractures (i.e. mode I fractures with no throw), (2) extensional-shear fractures (i.e. mixed-mode fractures with open and lateral shear components of offset, but no throw), and (3) normal faults (i.e. throw across subvertical, surface-breaching fault segments). Measurements of extension direction, extension magnitude (i.e. opening, or aperture), mode (i.e. mode I or mixed mode; Fig. 2), and individual trace azimuth were gathered using traditional compass techniques (Fig. 2). Cut-off line positions for surface-breaching fault segments and hanging wall monoclines were mapped remotely using satellite imagery (GoogleEarth ${ }^{\mathrm{TM}}$ and World-View2) and topographic datasets (aerial lidar; Hawai' $i$ only). The resulting combined dataset contains approximately 2500 measurements and covers up to 3 orders of length magnitude. Where applicable, fault throw was estimated, either in the field, or remotely using high-resolution topographic datasets. It should be noted that the majority of the structures encountered in the study areas are extension fractures that do not involve a shear component, typical of deformation patterns seen in many nearsurface rift zones (e.g. Grant and Kattenhorn, 2004; Casey et al., 2006).

Fault and intrusion geometry and kinematic data were collected over several field seasons for Kangerlussuaq and the Faroe Islands, from over 400 localities (Walker, 2010; Walker et al., 2011). Structures were mapped using a combination of field observation and remote sensing analysis. Fault slip data from localities were grouped based on observed cross-cutting relationships where possible, or grouped by fault strike where direct cross-cutting relationships were not clear. Kinematic inversions were performed using the methods described in Walker et al. (2011).
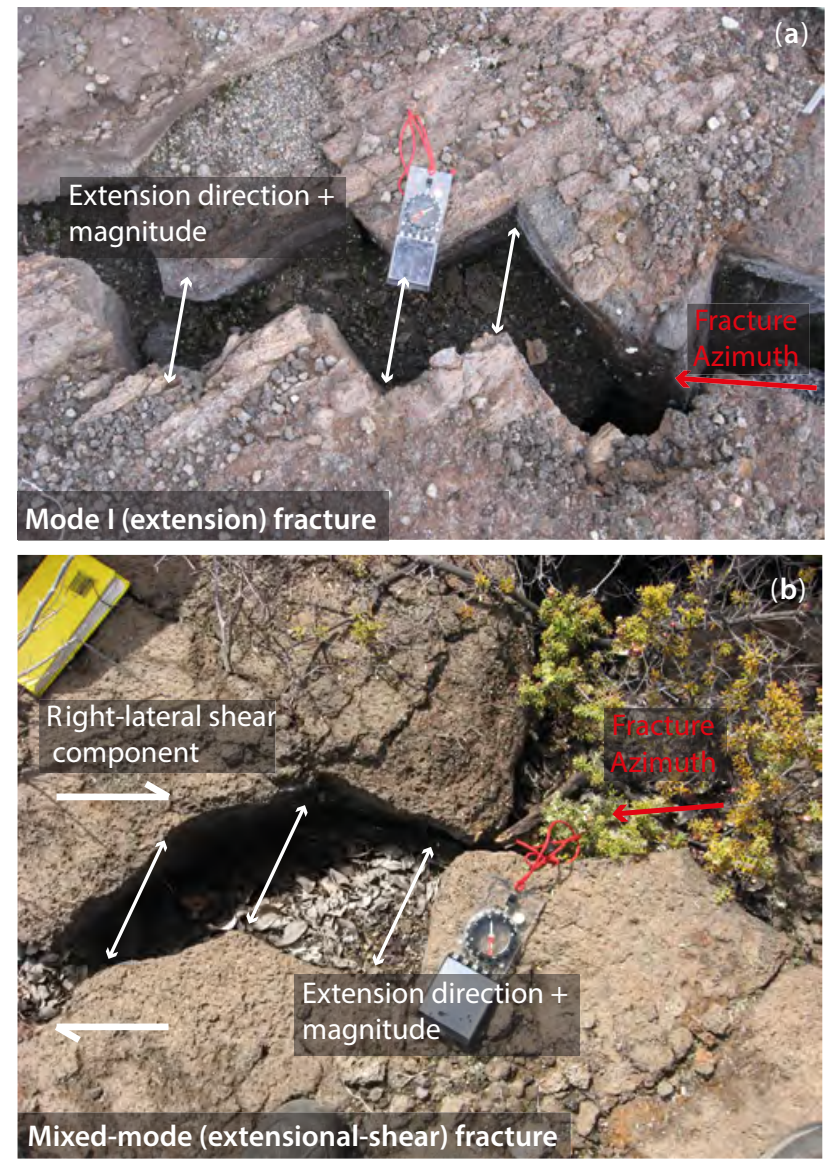

Figure 2. Measurement of fracture geometry and kinematics. (a) Mode I (extensional) opening across pre-existing cooling joint surfaces allows the traditional measurement of extension direction and magnitude (aperture) and fracture trace azimuth. The fracture in the image shows an aperture of $0.2 \mathrm{~m}$ and an opening direction of $142^{\circ}$, orthogonal to the azimuth of the fracture $\left(052^{\circ}\right)$. (b) Mixed-mode (extensional shear) opening across a cooling joint. The fracture in the image shows an aperture of $0.25 \mathrm{~m}$ and an opening direction of $036^{\circ}$, oblique to the azimuth $\left(080^{\circ}\right)$ of the fracture, indicating a component of right-lateral shear.

\section{Field study areas}

\subsection{Kilometre-scale segmented fault systems}

\subsubsection{The Koa'e fault system, Hawai'i}

The Koa'e fault system is $\sim 12 \mathrm{~km}$ long and $\sim 3 \mathrm{~km}$ wide and is located on the south flank of Killauea Volcano, the youngest intraplate volcanic system on the island of Hawai ' $i$. The Koa'e system connects two prominent rift zones: the Southwest and East rift zones, (SWRZ and ERZ; Fig. 3a), to form a near-continuous rift system that accommodates regional NNW-SSE extension (Dzurisin et al., 1984; Wright and Klein, 2006; Poland et al., 2012). 

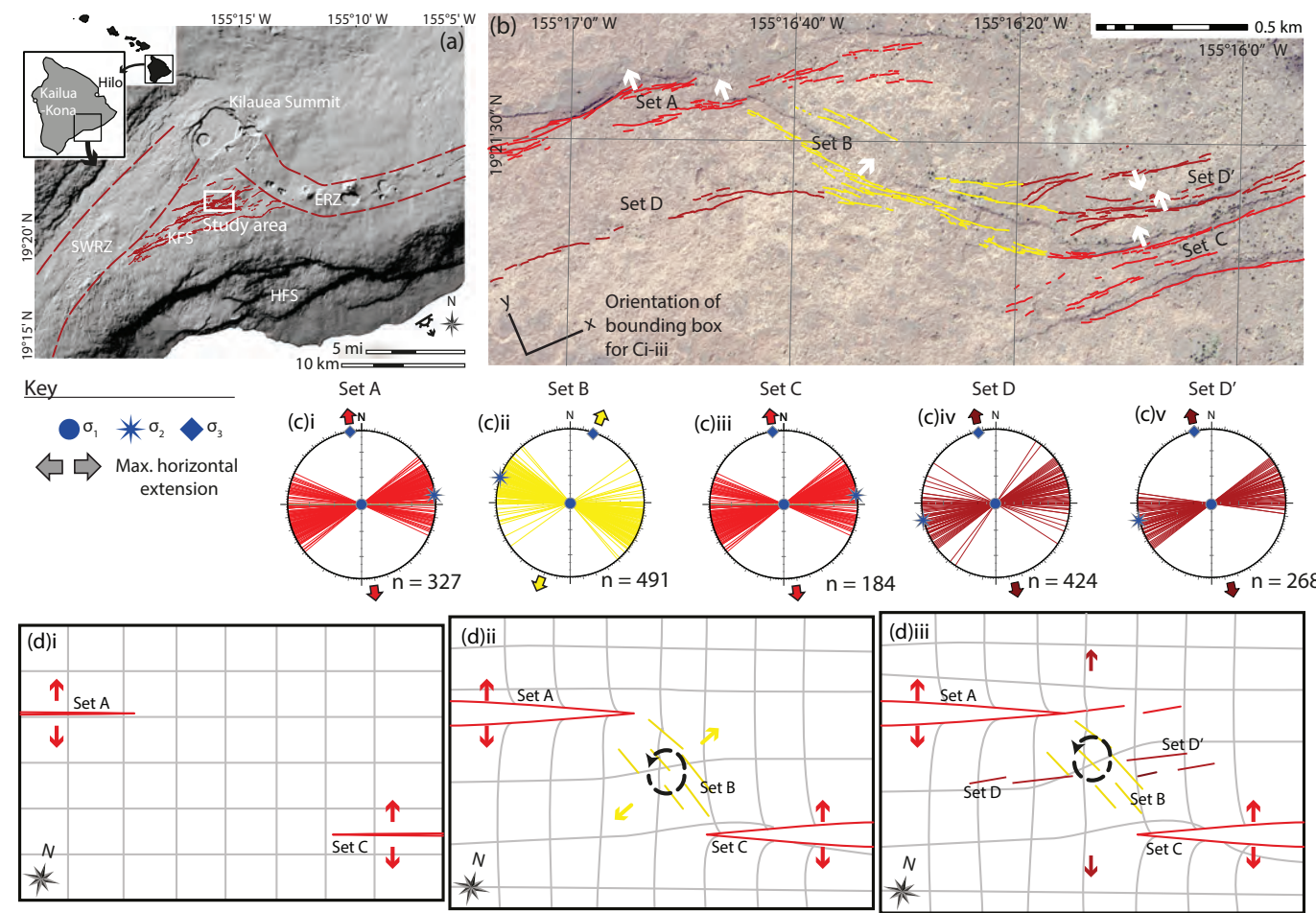

Figure 3. (a) Simplified structural element map of Kîlauea Volcano, showing the study area within the Koa'e fault system (KFS). ERZ: East Rift Zone. SWRZ: Southwest Rift Zone. HFS: Hilina Fault System. Inset shows relative position of A, on the south coast of the island of Hawai'i. (b) WorldView-2 image of the study area showing the distribution and orientation of mapped fractures. White arrows indicate dip directions of monocline limbs and fault scarps. (c) Lower-hemisphere stereographic projections showing measured fault and/or fractures as planes and measured extension directions for each of the three structural sets. (d) Proposed schematic evolution of fault sets: (i) propagation of the main rift-fault set (sets A and C); (ii) interaction between sets A and C produces deficits of heave displacement, requiring vertical axis block rotation in the relay zone, and local reorientation of extension direction (set B); and (iii) development of new rift-parallel structures (set D; Swanson et al., 2017). The bounding box is aligned with first-order rift faults (sets A and C).

Based on orientation, extension direction, and spatial distribution, we identify two dominant fault and fracture sets in the Koa'e fault system: (1) ENE-WSW-striking (ERZ parallel) first-order fractures and normal faults that accommodate the regional NNW-SSE extension (sets A, C, and D; Fig. 3b) and (2) NW-SE-striking (ERZ-oblique) fractures that accommodate a more localized NE-SW extension (set B; Fig. 3b). The NW-SE-striking (ERZ-oblique) fractures (set B) are not ubiquitous throughout the Koa'e fault system. Instead they are restricted to zones of underlap between first-order rift faults: here, in the underlap between two major ENE-WSW-striking (ERZ-parallel) normal faults: sets A and C (Figs. 2 and 3). NW-SE-striking fractures are therefore described as second-order structures, ancillary to first-order bounding rift faults (sets A and C). All measured fractures in this NW-SE-striking set (set B) show purely extensional opening (Fig. 3b), resulting in a local extension direction that is $\sim 40^{\circ}$ clockwise of the regional (NNW-SSE) extension. We found no evidence for cross-cutting relationships between ENE-WSW- and NW-SE-striking fracture sets (sets A, C, and B; Fig. 3c(i, ii)). Measurements of fresh ground cracks following the last major rifting event that affected the Koa'e (December 1965) identified fresh ENE-WSW-striking extension fractures (here labelled set D; Fig. 3b, c(iii); Swanson et al., 2017), at which time fault and fracture sets A, B, and $\mathrm{C}$ had already been mapped; we infer here that these existing sets either formed in a cyclic sequence or formed contemporaneously.

The ENE-WSW-striking sets comprise first-order normal faults that dip dominantly to the north and demonstrate maximum throws of $\sim 5-12 \mathrm{~m}$ and footwall fractures with maximum apertures of $\sim 4-5 \mathrm{~m}$ (sets $\mathrm{A}$ and $\mathrm{C}$; Fig. 4). Individual surface-breaching normal fault segments show trace lengths of up to $\sim 200 \mathrm{~m}$ and exhibit discontinuous faultparallel monoclinal flexures in fault hanging walls. Fault sets A and C (Figs. 3 and 4 ) are separated by $\sim 800 \mathrm{~m}$ (measured in a NNW-SSE axis, parallel to the fault dip) and underlap by $200 \mathrm{~m}$. The NW-SE-striking fracture set is limited to this zone of underlap and records smaller strains, with no surfacebreaching fault segments, and fractures with trace lengths $<200 \mathrm{~m}$ and apertures $<2.5 \mathrm{~m}$ (set B; e.g. Fig. 4b). We in- 

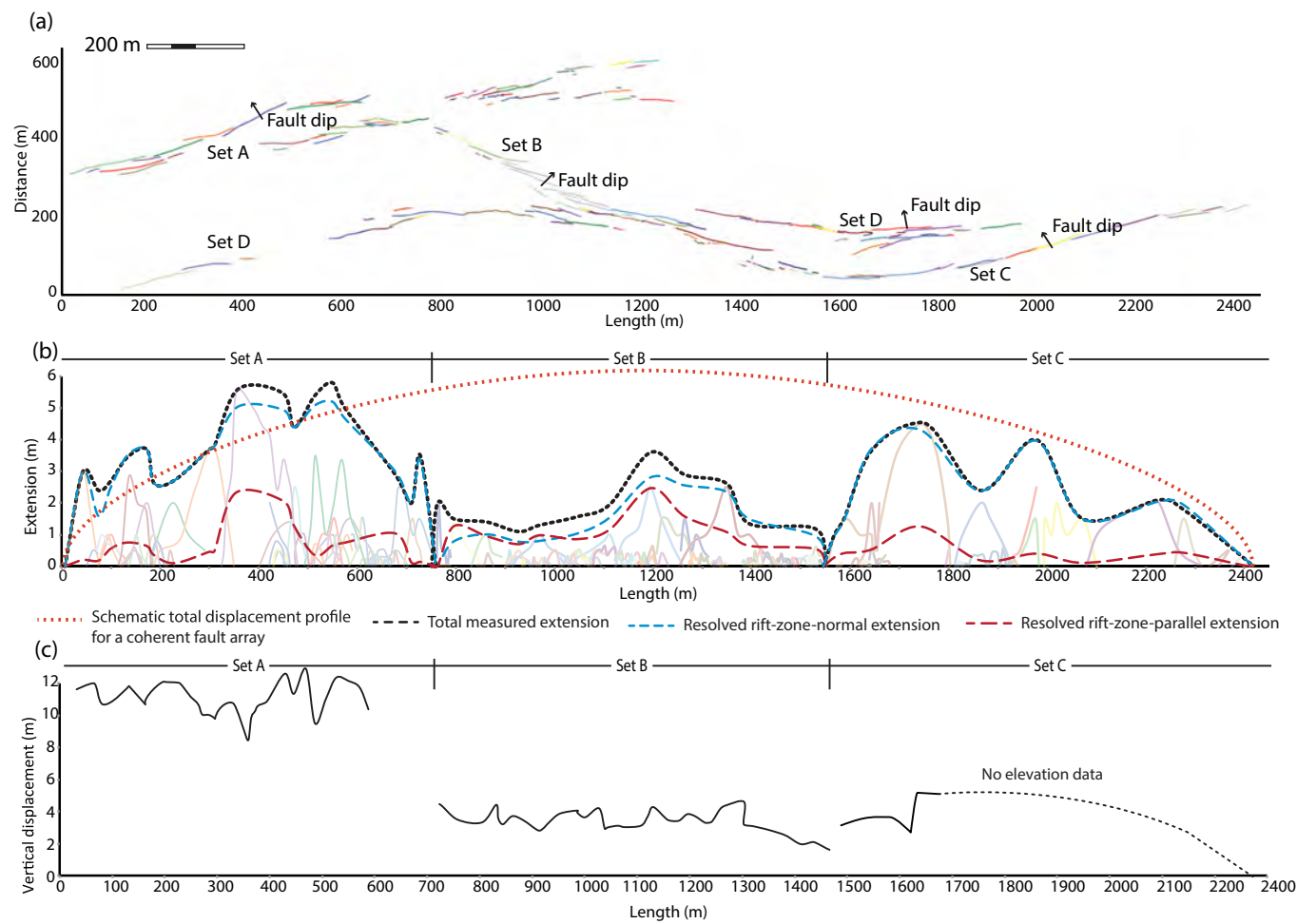

Figure 4. (a) Distribution of mapped fractures in the study area. (b) Profile of horizontal displacement (heave) vs. length for mapped fractures. The dotted grey line indicates cumulative aperture for each set. Dashed blue lines indicate the calculated component of rift-zonenormal extension on each fracture set. Dashed red lines indicate the calculated component of rift-zone-parallel extension on each fracture set. The dotted orange line represents a hypothetical total displacement profile for a single fault (e.g. Gupta and Scholz, 2000), or fully linked, mature fault array (e.g. Childs et al., 2017), in which the maximum displacement is located centrally along the fault or array. (c) Profile of estimated vertical displacement (monocline height and throw) vs. length for segments of surface-breaking faults. No evidence for throw was identified along the NW-SE-striking fractures of set B. With no surface-breaching fault segments along the NW-SE-striking fractures of set $\mathrm{B}$, we present monocline height values only. The dotted line indicates extent of elevation data when the profile is estimated from field observations and aerial imagery.

terpret this zone of underlap to be a relay zone, bound by fault sets $\mathrm{A}$ and $\mathrm{C}$.

Figure 4 shows the summed surface extensional strains for each fracture set in the mapped area, as a function of the total plane-normal extension (i.e. extension measured in the dip azimuth), and the resolved contribution to NNW-SSE (regional) extension. Extension on set $\mathrm{B}$ fractures is in deficit compared to the surrounding regions with a total measured heave (aperture) peak of $\sim 3.5 \mathrm{~m}$ compared to $\sim 6 \mathrm{~m}$ for the northern bounding set $\mathrm{A}$ and $4.5 \mathrm{~m}$ for the southern bounding set C (Fig. 4b). A vertical displacement (throw) deficit is also recognized (Fig. 4c) from aerial lidar datasets with up to $\sim 12 \mathrm{~m}$ of displacement measured across fault $\mathrm{A}$ and up to $\sim 4 \mathrm{~m}$ across fault $\mathrm{C}$ and the monocline along fracture set B. The relative contributions of the components of rift-zonenormal and rift-zone-parallel extension also follow this distribution with a centrally located minimum of $3 \mathrm{~m}$ (rift-zonenormal extension) on linking set $\mathrm{B}$. This minimum is bound to the north by $\sim 5 \mathrm{~m}$ of rift-normal extension on set $\mathrm{A}$ and $\sim 4 \mathrm{~m}$ on set $\mathrm{C}$ to the south. Calculated rift-zone-parallel ex- tension is minor on southern bounding set $\mathrm{C}$ (up to $1.2 \mathrm{~m}$ ) and peaks are approximately equal on the linking set $\mathrm{B}$ and northern bounding set A (up to $2.5 \mathrm{~m}$ ). Although set B accommodates a component of rift-zone-normal extension, this set contributes relatively little to the regional extensional strain as a whole (Fig. 4b, c).

\subsubsection{The Krafla fissure swarm, Iceland}

Iceland sits at the junction between the northern termination of the Reykjanes Ridge, and the southern termination of the Kolbeinsey Ridge, with present-day rifting on the island accommodated by the Neovolcanic Zone. We focus here on the well-exposed Gjástykki valley, $10 \mathrm{~km}$ north of Krafla, within the Krafla fissure swarm (Fig. 5). Regional NW-SE extension in the Krafla fissure swarm is accommodated dominantly on surface-breaching normal faults with maximum throws of 10-30 m; monoclinal surface flexures occur as discontinuous structures in some fault hanging walls, but are rare compared to the Koa'e fault system. The focus of this 

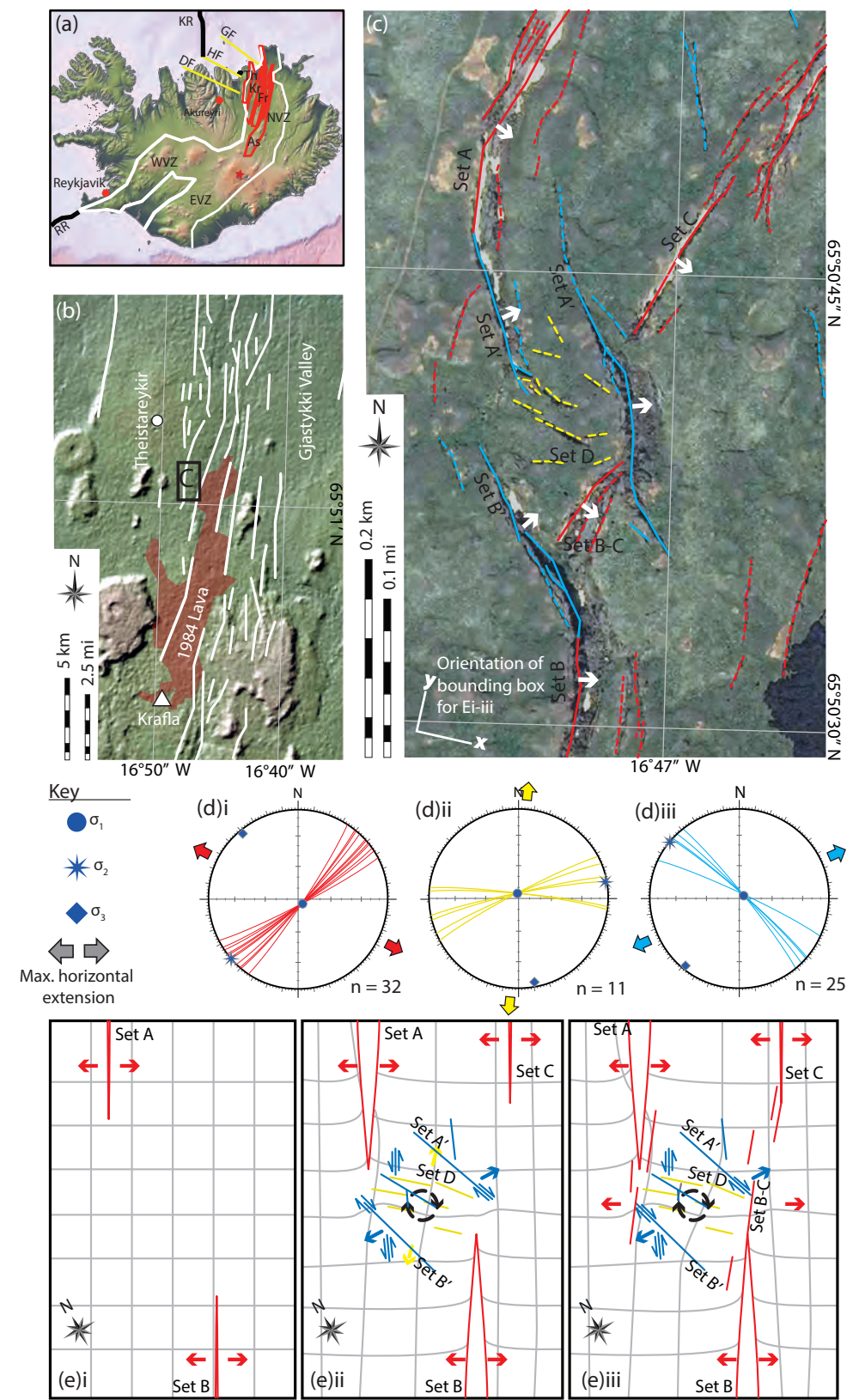

Figure 5. (a) Map of Iceland highlighting the major tectonic elements: Reykjanes Ridge (RR); the Kolbeinsey Ridge (KR); South Iceland Seismic Zone (SISZ); West Volcanic Zone (WVZ); East Volcanic Zone (EVZ); Neovolcanic Zone (NVZ: the axial rift zone); Askja volcanic centre (As); Fremri-Namur volcanic centre (Fr); Krafla volcanic centre (Kr); Theistareykir volcanic centre (Th); and the Tjörnes Fracture Zone (TFZ) comprising the Dalvík lineament (DF), the Húsavík-Flatey Fault (HF), and the Grimsey lineament (GF). (b) Location of study area in the Gjástykki valley within the Krafla fissure swarm. White arrows indicate dip direction for fault scarps in the area. (c) Mapped structures in the study area, colour-coded based on orientation and kinematics: (1) rift-zone-parallel faults and fractures (red); (2) rift-zoneoblique faults and fractures (blue); and (3) rift-zone-normal fractures (yellow). (d) Lower-hemisphere stereographic projections showing measured extension directions for each of the three structural sets. (e) Proposed schematic evolution of fault sets: (i) propagation of the main rift-fault sets A and B; (ii) interaction between sets A and B leads to a horizontal displacement deficit and vertical axis block rotation in the relay zone and induced local reorientation of extension direction accommodated on variably oriented ancillary faults and fractures; and (iii) continued propagation of the main rift faults (A, B, and C) leads to the development of new rift-parallel structures. The bounding box is aligned with first-order rift faults (sets $\mathrm{A}$ and $\mathrm{B}$ ). 
study area is a relay zone surrounding the tips of en échelon rift-zone-parallel normal faults that strike NNE-SSW (Fig. 5b, c).

Faults and footwall fractures in the Krafla system can be separated into three structural sets based on their orientation, extension direction, and extension mode (Fig. 5c, d): (1) NNE-SSW-striking (parallel to the rift axis: sets A, B, C) first-order fractures and normal faults, which accommodate rift-zone-normal (WNW-ESE) extension; (2) NW-SEstriking (rift-oblique: sets A', B') normal faults and mixedmode (extensional shear) fractures that accommodate riftzone-oblique (ENE-WSW) extension; and (3) WNW-ESEstriking (rift-normal: set D) fractures that accommodate riftzone-parallel (NNE-SSW) extension. The distribution of NW-SE (sets A', B') and WNW-ESE-striking (set D) fractures is limited to a zone of underlap ahead of two first-order rift-parallel normal faults (sets A and B). Both the NW-SE and WNW-ESE sets are cut by a NNE-SSW-striking normal fault showing up to $2 \mathrm{~m}$ of throw and a set of fractures with up to $3 \mathrm{~m}$ of aperture (set B-C). These later structures connect NW-SE-striking sets B' and A' and accommodate rift-zone-normal extension. Hence, rift-parallel-striking faults and fractures, which cut, and are cut by, obliquely oriented sets, are the first and final stages of observed deformation in the rift zone, respectively (Fig. 5e). No consistent cross-cutting relationships are observed between riftoblique- and rift-normal-striking structures (Fig. 5e), suggesting that they formed contemporaneously.

Figure 6 shows the summed extensional strains for each fracture set in the mapped area, as a function of the planenormal extension, and the resolved contribution to WNWESE (regional) extension. Rift-oblique-striking fault and fracture sets (sets A', B'; Figs. 5c, 6a) are well-developed and branch away from the tips of rift-parallel-striking faults, with tensile openings of up to $\sim 8 \mathrm{~m}$ (Fig. $6 \mathrm{~b}$ ) and estimated maximum throws of $\sim 20 \mathrm{~m}$. Rift-normal-striking fractures (set D; Figs. 5c, 6a) represent the smallest strains in the relay zone with maximum fracture apertures of up to $2 \mathrm{~m}$ (Fig. 6b) and no vertical displacement (throw). Based on the total measured extension profile (grey dotted line in Fig. 6b), which represents a fully linked fault array that accommodates regional extensional strain, the underlap zone does not appear to be in deficit compared to the surrounding regions. There is an approximately centralized total aperture peak of $\sim 14 \mathrm{~m}$, compared to $8 \mathrm{~m}$ for southern bounding set $\mathrm{B}$ and $13.5 \mathrm{~m}$ for northern bounding sets A and C (Fig. 6b). When the directional components of this total measured extension are plotted, however, we are able to define a pronounced heave deficit in the relay zone (blue and red dashed lines in Fig. 6b). Resolved rift-zone-normal extension is greatest on northern bounding sets $\mathrm{B}$ and $\mathrm{C}(\sim 12 \mathrm{~m})$, followed by southern bounding set $B(\sim 10 \mathrm{~m})$, with a low of $\sim 9 \mathrm{~m}$ total aperture for linking fault and fracture sets (A', B', D, BC; Fig. 6b) in the overlap zone. Rift-zone-parallel extension within the relay zone is significant for the area at $\sim 8 \mathrm{~m}$, com- pared to a maximum of $1 \mathrm{~m}$ for southern bounding set $\mathrm{B}$ and a maximum of $5.5 \mathrm{~m}$ for northern bounding sets $\mathrm{A}$ and $\mathrm{C}$.

\subsubsection{Summary and interpretations for the Koa'e and Krafla fault systems}

Regional extension in the Koa'e and Krafla fault systems is accommodated by segmented rift-zone-parallel faults that are discontinuous and underlapping at the present-day topographic surface. Relay zones, located between the lateral terminations of first-order bounding rift faults, transfer displacement across second-order, ancillary faults and fractures that strike obliquely and normal to the bounding fault segments. Profiles of displacement (extension) length show an extension deficit in the regional extensional strain, relative to a theoretical displacement profile for fully linked fault array (Figs. $4 \mathrm{~b}$ and $6 \mathrm{~b}$ ). Fracture sets that strike at a low angle to the main rift zone $\left(<45^{\circ}\right)$ show extensional-shear opening (e.g. Krafla; Fig. 5) and must therefore accommodate a combined rift-zone-normal extension direction (i.e. contributing to the regional extension) and a component of riftzone-parallel shortening. Fracture sets that strike at high angles (i.e. $>45^{\circ}$ ) to the main rift-parallel faults are dominantly extensional and therefore provide a smaller contribution to the regional extension but nevertheless represent a significant component of rift-zone-parallel extensional strain. Simultaneous orthogonal extension directions produce an area of inherently 3-D strain within the relay zones.

Observed rift-oblique extensional-shear fault and fracture sets are dominantly synthetic to each other, rather than bimodal (i.e. conjugate). As such, we infer that they facilitate a vertical axis rotation between the main rift faults, similar to a bookshelf-like faulting mechanism (Mandl, 1987). A bookshelf rotation about a vertical axis would involve a riftzone-normal material thickening but must also involve a riftzone-parallel material thinning (cf. bookshelf rotations about a horizontal axis, which accommodate horizontal extension and vertical thinning). Fractures with strikes orthogonal to the main rift faults in the Krafla study area, however, display extensional openings that may counteract this shear-induced shortening, leading to an overall volume increase within the rift zone. At the surface, this volume increase is accommodated by open cracks, but may be accommodated in the subsurface by normal faults and dike emplacement oblique to and normal to the rift axis.

\subsection{Segmented basin systems on a scale of tens of kilometres: the NE Atlantic passive margins}

The pre-break-up configuration of the NE Atlantic involved the development of offset spreading segments (the Reykjanes and Ægir systems; Fig. 7b-d) that accommodated a regional NW-SE extension, culminating in break-up and formation of the contiguous NE Atlantic (Gernigon et al., 2012). The Faroe Islands and Kangerlussuaq were located either side of 

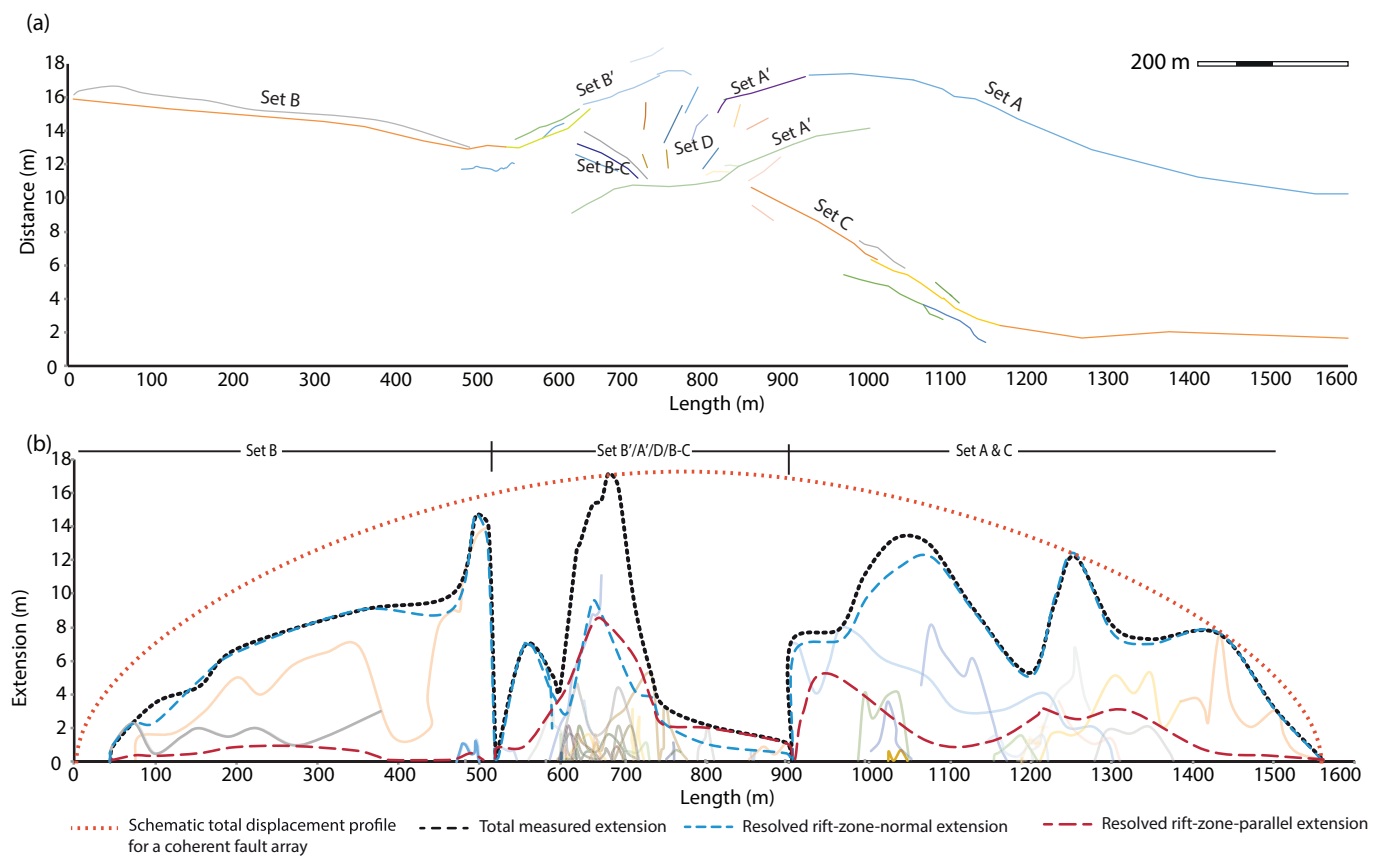

Figure 6. (a) Distribution of mapped faults and fractures in the study area. (b) Profile of horizontal displacement (extension or heave) vs. length for mapped fractures. The dotted black line indicates the total measured extension for structures in each set. Dashed blue lines indicate the calculated component of extension on each fracture set that occurs in a direction orthogonal to the rift zone. Dashed red lines indicate the calculated component of extension on each fracture set that occurs in a direction parallel to the rift zone. Extension across the system as a whole is represented by a hypothetical displacement profile for a fully linked, mature fault array in which the maximum displacement is located centrally along the fault, or array, and tapers to zero at the lateral tips (dotted orange line).

the SW termination of the Ægir spreading ridge segment and $\mathrm{NE}$ termination of the Reykjanes Ridge segment (Fig. 7a), and both ridges record the initiation of oceanic spreading in the early Ypresian ( 55-53 Ma; Gernigon et al., 2012) (Fig. 7c). Prior to NE Atlantic spreading, the Faroe Islands and Kangerlussuaq were located about $80 \mathrm{~km}$ apart (Ellis and Stoker, 2014). The two regions can therefore be considered remnants of a very large $\left(\sim 5 \times 10^{4} \mathrm{~km}^{2}\right)$, breached relay system between the eventual ridge segments.

Both areas are dominated by Cenozoic North Atlantic Igneous Province lavas and intrusions, and both exhibit sequential deformation phases that are constrained as having formed prior to, and contemporaneous with, Atlantic opening (Walker et al., 2011; Roberts and Walker, 2016; Guarnieri, 2015). Here we present a combination of new geometric and kinematic data for the Kangerlussuaq region of east Greenland, and published data for the Faroe Islands, based on field and remote mapping of upper crustal (1-6 km depth maximum) faults and intrusions. We do not seek to directly compare the scale or regional dynamics of continental margins with volcanic island faulting or mid-ocean ridges, but rather the kinematic evolution of segmented fault systems. Our comparison is between the surface expression of fault sets (Koa'e and Krafla) and near-surface brittle deformations on the Atlantic margins. We do not seek here to address full crustal thickness stretching models.

\subsubsection{Kangerlussuaq, east Greenland Atlantic margin}

Igneous activity in the Kangerlussuaq region of east Greenland (Fig. 8a), associated with continental break-up, is thought to have occurred in three phases: $62-59,57-54$, and 50-47 Ma (Tegner et al., 1998), with emplacement of the $7 \mathrm{~km}$ wide, layered gabbroic Skaergaard intrusion at $\sim 56 \mathrm{Ma}$ (Wotzlaw et al., 2012). Deformation is characterized by geometrically and temporally linked suites of cross-cutting faults and dikes, hosted within the Archaean basement and Cretaceous-Cenozoic stratigraphy (Fig. 8b, c). Importantly, faults and dikes cut the Skaergaard intrusion and compositionally similar macrodikes (e.g. the Miki Fjord macrodike; Fig. 8a, c) that are thought to be contemporaneous with emplacement of the Skaergaard intrusion (Holm et al., 2006; Holwell et al., 2012), giving a well-constrained maximum age for the deformation.

The $\sim 500 \mathrm{~m}$ thick Miki Fjord macrodike strikes parallel to the margin and Reykjanes Ridge segment (i.e. NESW; Fig. 8a, c) and accommodates margin-normal (NWSE) extension. The macrodike is cut and offset by ESEWNW oblique-extensional faults, which show lateral displacements of at least $\sim 100 \mathrm{~m}$ (e.g. Fig. 8c) and form a 


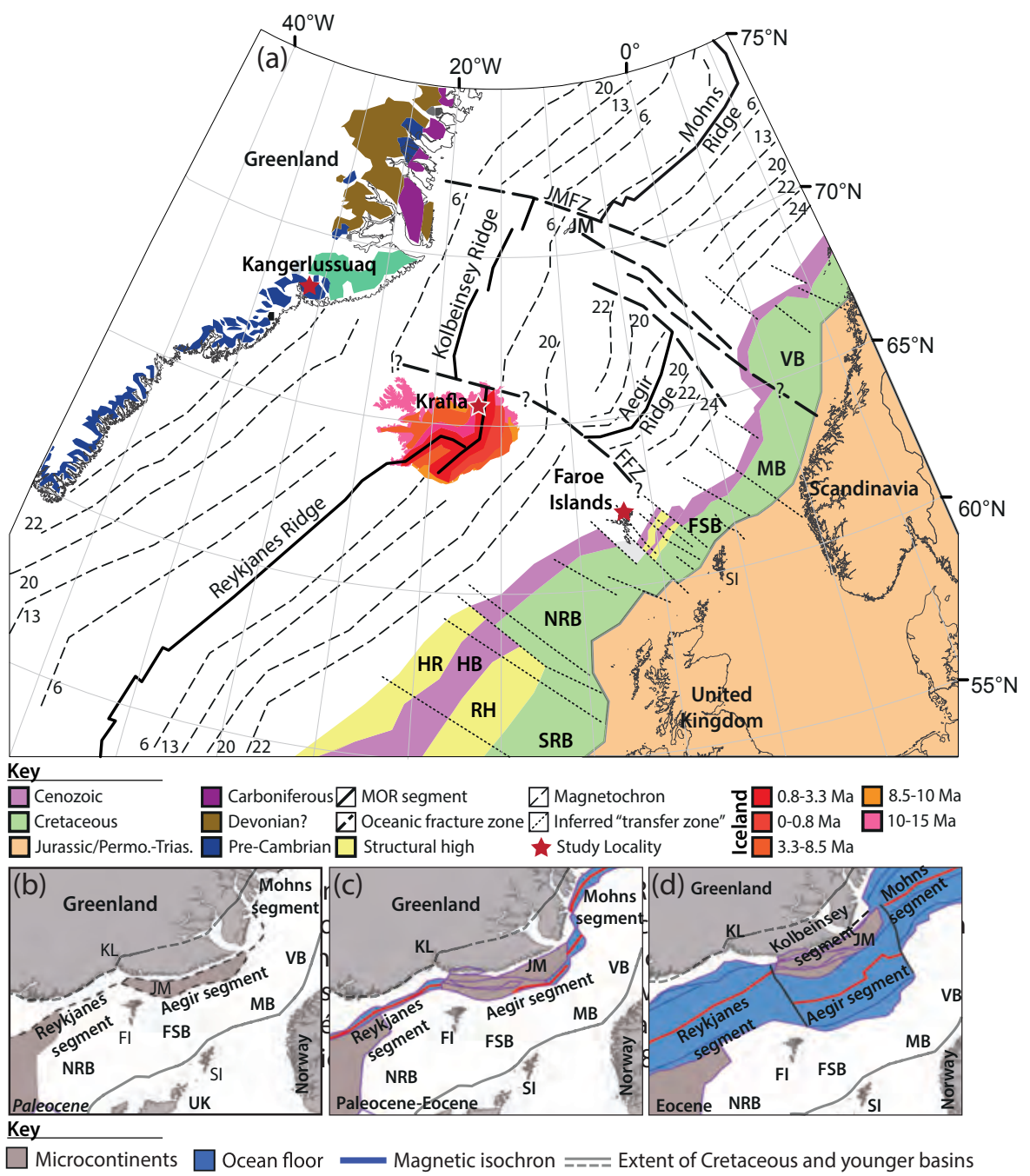

Figure 7. (a) NE Atlantic tectonic elements map: Hatton Rise (HR), Hatton Basin (HB), Rockall High (RH), South Rockall Basin (SRB), North Rockall Basin (NRB), Faroe-Shetland Basin (FSB), Shetland Islands (SI), Møre Basin (MB), Vøring Basin (VB), Jan Mayen (JM), Jan Mayen Fracture Zone (JMFZ), Tjörnes Fracture Zone (TFZ), and Faroes Fracture Zone (FFZ). The map was compiled using basin ages from Doré et al. (1997), oceanic magnetic anomalies from Gaina et al. (2009), and Iceland stratigraphic ages from Doré et al. (2008). Study localities are indicated by stars. (b-d) Schematic model for a segmented opening of the NE Atlantic during the Paleogene (after Ellis and Stoker, 2014). Faroe Islands (FI); Kangerlussuaq (KL).

conjugate set with ENE-WSW-striking faults, which accommodates margin-oblique (N-S) extension (Fig. 8d(i)). These faults also cut the Skaergaard intrusion (Fig. 8b) and strike parallel to conjugate dikes, with which they show a mutual cross-cutting relationship. Skaergaard additionally hosts margin-normal (N-S to NW-SE) faults and dikes, accommodating margin-parallel (NE-SW) extension (Fig. 8b, d(ii)), which are cut by the margin-oblique structures (Fig. 8b). Locally, margin-parallel dikes are observed in the Skaergaard intrusion, which cut both of those sets (see also Irvine et al., 1998).

\subsubsection{The Faroe Islands, European Atlantic margin}

Deformation in the Faroe Islands (Fig. 9a) is characterized by sets of cross-cutting faults and intrusive igneous sheets that reflect reorientation of the local extension vector during and following emplacement of the Faroe Islands Basalt Group (57-54 Ma; Passey and Jolley, 2009; Fig. 9b). Based on fault and fracture geometry and kinematics (including paleostress analysis), together with cross-cutting relationships, Walker et al. (2011) identified three main structural sets (Fig. 9c, d, e). These are (oldest to youngest): (1) N$\mathrm{S}$ and NW-SE-striking normal faults and dikes (marginnormal strike; Fig. 9c, e(i)) that accommodate E-W to NESW extension; (2) ENE-WSW to ESE-WNW conjugate 

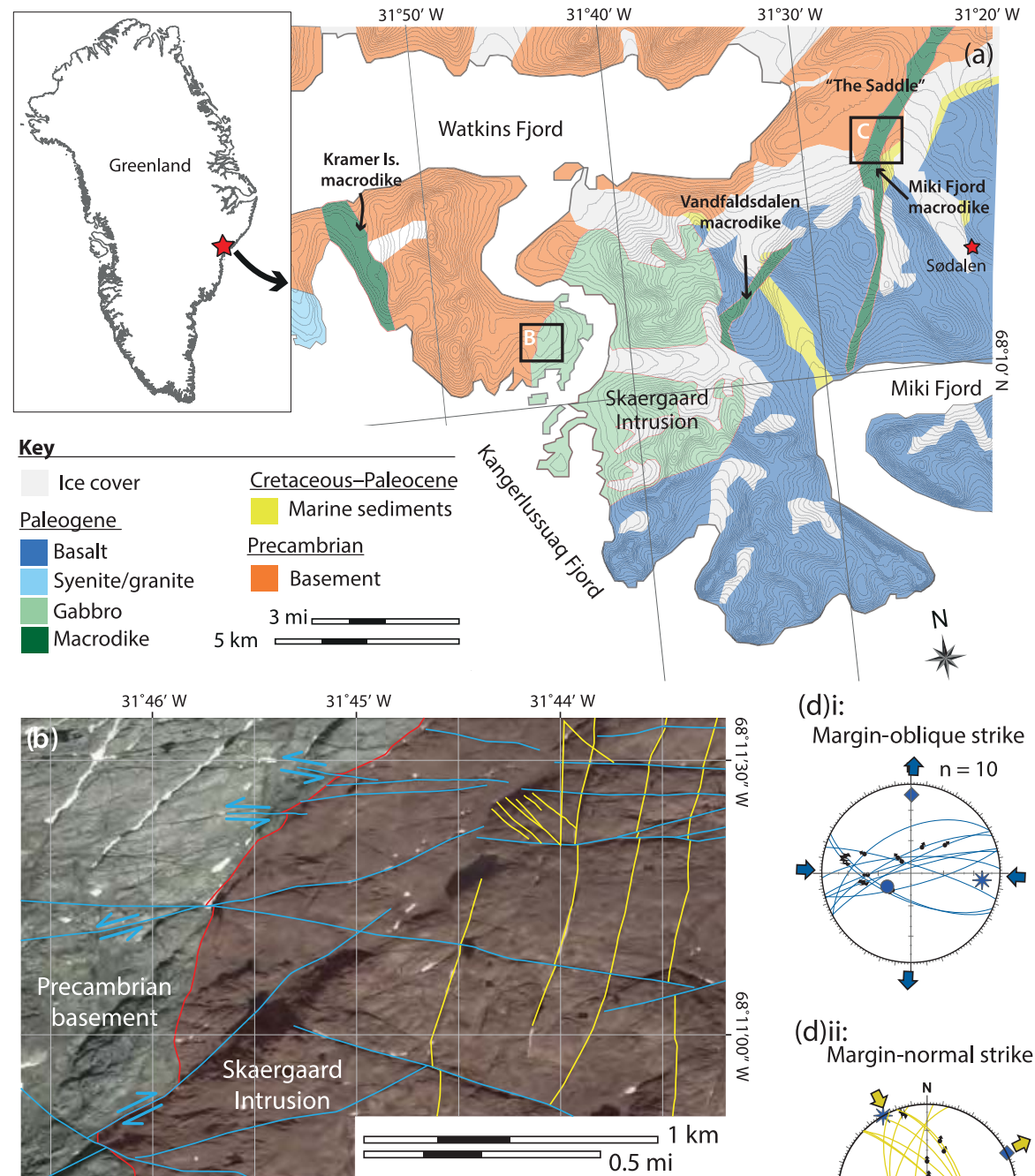

(d)i:

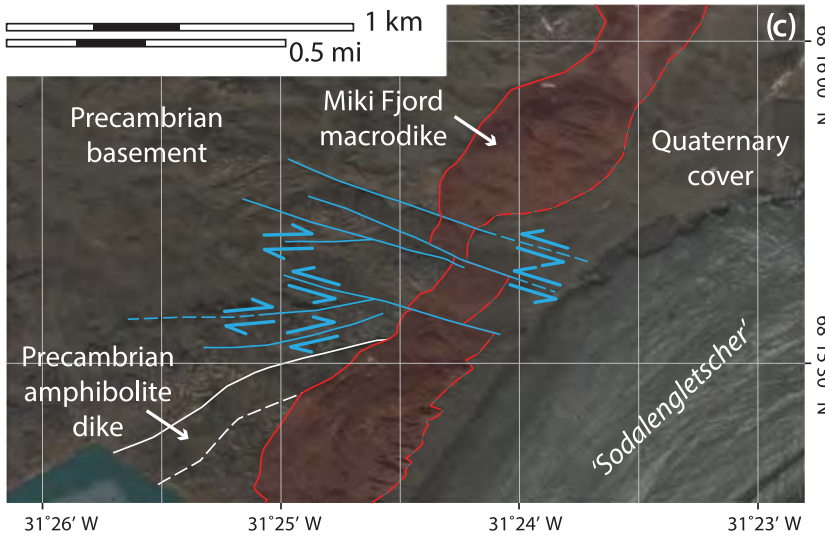

Margin-oblique strike

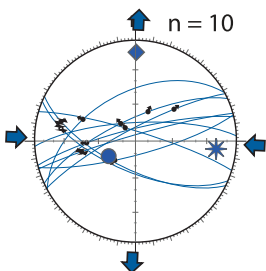

(d)ii: Margin-normal strike

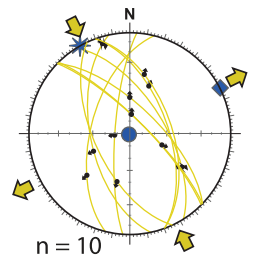

Key

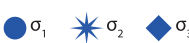

$\diamond$

Max. horizontal extension

$\Rightarrow<$

Max. horizontal

compression

Figure 8. (a) Geological map of the Skaergaard intrusion and surrounding area (redrawn from Holwell et al., 2012). Contours indicate 50 m elevation intervals from sea level. (b) Margin-normal-striking faults and dikes, which are in turn cut by margin-oblique-striking faults and dikes, cut the Skaergaard intrusion. (c) Margin-oblique-striking faults cut the margin-parallel Miki Fjord macrodike. (d) Lower-hemisphere stereographic projections for relative-age-constrained examples of the three main fault sets observed. 

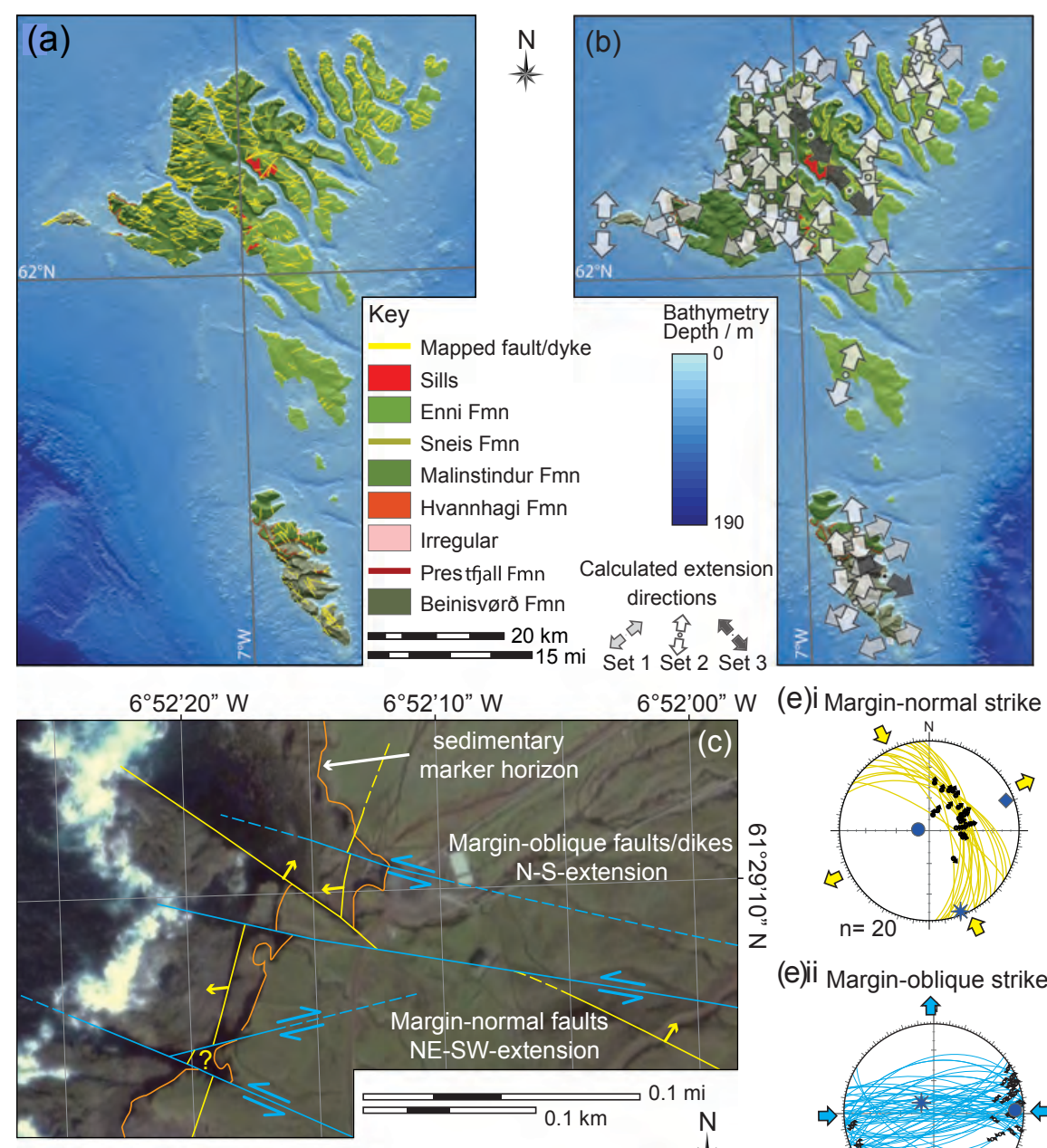

$6^{\circ} 52^{\prime} 10^{\prime \prime} \mathrm{W}$

$6^{\circ} 52^{\prime} 00^{\prime \prime} \mathrm{W}$

(e)i Margin-normal strike
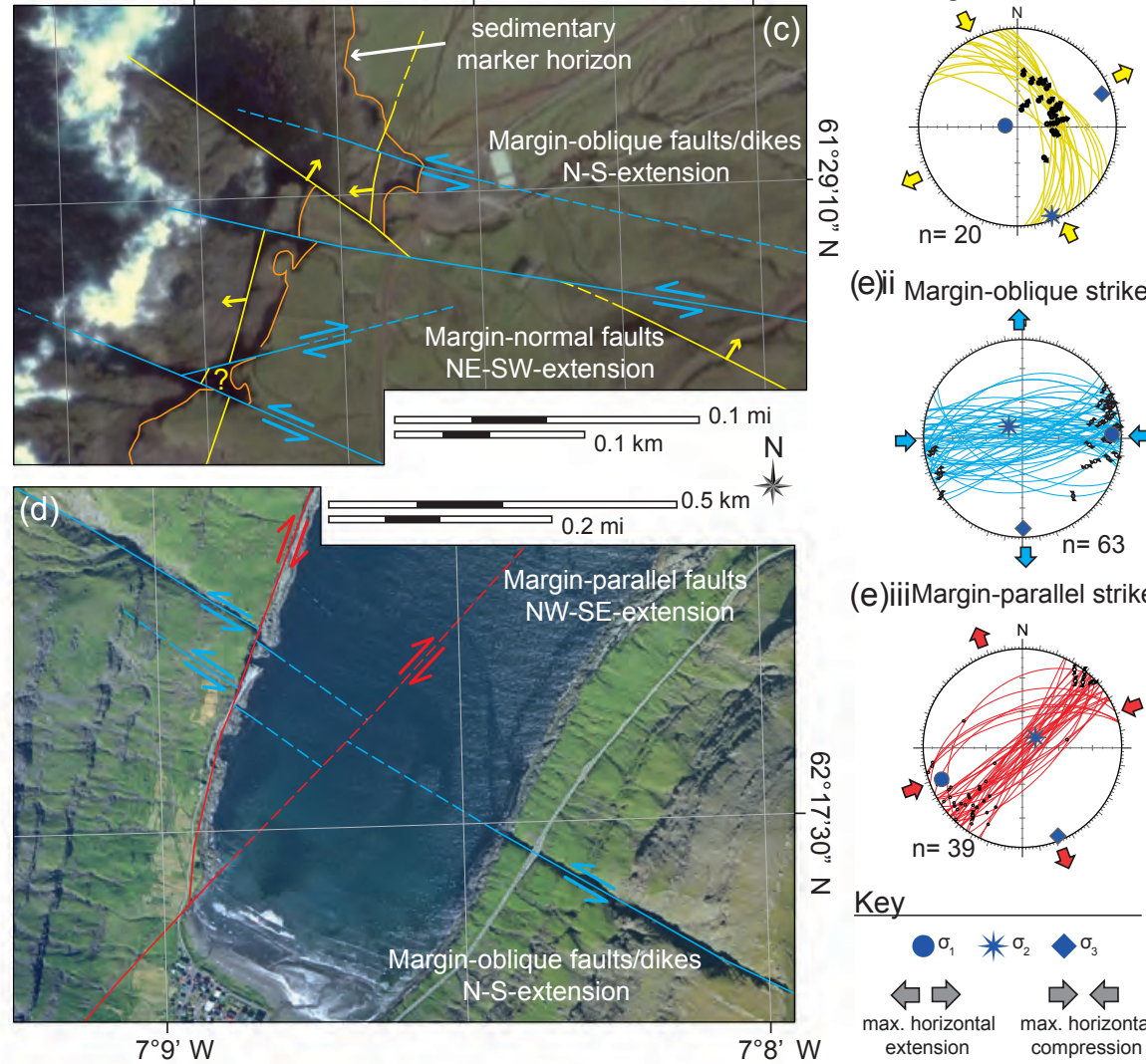

(e)ii Margin-oblique strike

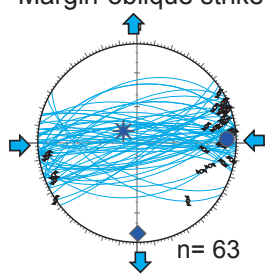

(e)iiiMargin-parallel strike

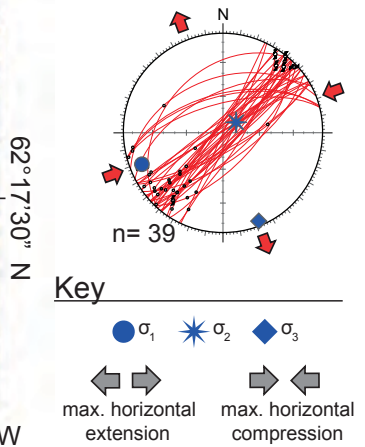

Figure 9. (a) Onshore structural element map of the Faroe Islands. (b) Inferred extension directions indicating an island-wide anticlockwise rotation in extension direction through time. (c) Margin-oblique faults cut margin-normal faults. (d) Margin-parallel faults cut rift-oblique faults and dikes. (e) Lower-hemisphere stereographic projections for relative-age-constrained examples of the three main fault sets observed. 
dikes and strike-slip faults (margin-oblique strike; Fig. 9c, d, e(ii)) that accommodate N-S extension; and (3) NE-SW and NNE-SSW-striking strike-oblique-slip faults (marginparallel strike; Fig. 9d, e(iii)) that accommodate NW-SE extension. Walker et al. (2011) interpreted the fault and intrusion sets as representing a progressive anticlockwise rotation in the extension direction before, during, and following continental break-up. Set 1 (NW- and N-striking) faults are associated with thickness variations in the Faroe Islands Basalt Group (Passey and Jolley, 2009), suggesting that they are Paleocene in age. Using U-Pb geochronology for calcitebearing fault rocks, Roberts and Walker (2016) showed that although dating of set 2 (ENE- and ESE-striking) faults suggest they are mid-Eocene in age, there was potential for overlap with the ages of set 3 faults (Eocene and Miocene). Roberts and Walker (2016) were unable to constrain ages for set 1 faults, primarily due to high concentrations of common $\mathrm{Pb}$ and very low $\mathrm{U}$ concentration within the tested calcite. Margin-parallel (NE-SW-striking) faults accommodate extension parallel to the regional extension (i.e. NW-SE). The apparently oldest structures strike NW-SE and are parallel to postulated margin-normal strike-slip (transfer) fault zones reported along the margin (e.g. Ellis et al., 2009). In the Faroe Islands, this set accommodates minor $(\sim 1 \%)$ extension parallel to the margins and not strike-slip displacement. The prevalent strain recorded on the Faroe Islands, in terms of distribution and scale of displacements, is associated with the phase of N-S extension, in which ENE-WSW and ESEWNW conjugate dikes and strike-slip faults accommodate large lateral displacements (potentially up to hundreds of metres).

\subsubsection{Summary and interpretations for Kangerlussuaq and the Faroe Islands}

Faults and intrusions in Kangerlussuaq and the Faroe Islands record a consistent vertical axis rotation in extensional strains through time during a period of regional-scale NWSE extension (Walker et al., 2011). Structures that strike at a high-angle to the NE-SW-trending rift segments (i.e. NW-SE-striking structures) accommodate NE-SW (rift parallel) extension (Figs. 8d, 9e), rather than the dominantly strike-slip displacements that have been inferred from seismic and potential field datasets (e.g. Rumph et al., 1993; Ellis et al., 2009). Structures that strike at angles oblique to the rift segments (i.e. ENE- and ESE-striking faults and intrusions) accommodate a component of rift-subparallel shortening and extension oblique to the regional extension vector (Figs. 8d, 9e). Very few structures within the mapped areas accommodate rift-normal extension (NW-SE): the Miki Fjord macrodike accommodates up to $\sim 500 \mathrm{~m}$ horizontal extension, approximately in a NW-SE direction (Fig. 8c). These structures appear to be cut by, and cut, other structural sets, suggesting that they represent the first and final observed structures within the study areas.

\section{Discussion}

\subsection{Rift-zone-parallel extension associated with normal fault and rift systems}

The potential for displacement transfer and locally anomalous (with respect to far-field stresses), three-dimensional strains during fault linkage has been recognized in field studies (e.g. Ferrill et al., 1999; Ferrill and Morris, 2001; Koehn et al., 2008, 2010; Morris et al., 2014), scaled analogue models (e.g. Tentler and Acocella, 2010) (see Fig. 1), and numerical simulations (e.g. Segall and Pollard, 1980; Crider and Pollard, 1998; Kattenhorn et al., 2000; Maerten et al., 2002). For instance, Kattenhorn et al. (2000) demonstrated that, depending on the remote stress state, it is possible for a range of ancillary fault or fracture orientations to develop, recording variable amounts of extension parallel to the first-order faults. It is likely that such ancillary deformations record a component of bending strain (e.g. deformation bands in the Delicate Arch relay ramp, Arches National Park, Utah; see Rotevatn et al., 2007).

Bending strains are commonly analysed in the vertical plane where bedding is horizontal, but bending in the horizontal plane is challenging to identify due to a paucity of reference points. Normal faults in this study demonstrate vertical plane bending, about a horizontal axis, but associated with this extension is an observable component of bending in the horizontal plane, about a vertical axis. The development of strains associated with this bending does not develop instantaneously, rather each set may grow incrementally with slip accumulation on the bounding first-order faults as the relay zone distorts, nor are they restricted to one scale of observation. Such incremental, non-plane strains within evolving relay zones may be responsible for local instances of basin inversion, reverse and strike-slip faulting in otherwise extensional regimes, and complex compartmentalization characteristics (e.g. Lin and Okubo, 2016; Sachau et al., 2016). Importantly, for basin faults with displacements on the kilometre scale, significant amounts of horizontal bending and rotation are possible, driving associated strains that may go undetected.

The effect of horizontal heave displacement gradients requires vertical axis rotations (Ferrill and Morris, 2001) and may operate independently of scale (e.g. Morris et al., 2014), in the same manner as other fault characteristics. For instance, worldwide catalogues of relay zone geometry have demonstrated a power-law scaling relationship that covers approximately 8 orders of magnitude (e.g. Peacock, 2003; Long and Imber, 2011). Evidence for heave gradients and locally non-coaxial strains are described on a separation scale of tens of kilometres in the East African Rift (e.g. Koehn et al., 2008, 2010; Sauchau et al., 2016) and on a scale of hundreds of kilometres in the Baikal rift zone (Hus et al., 2006) and the Hold With Hope relay zone in NE Greenland (Peacock et al., 2000). These examples show many characteris- 


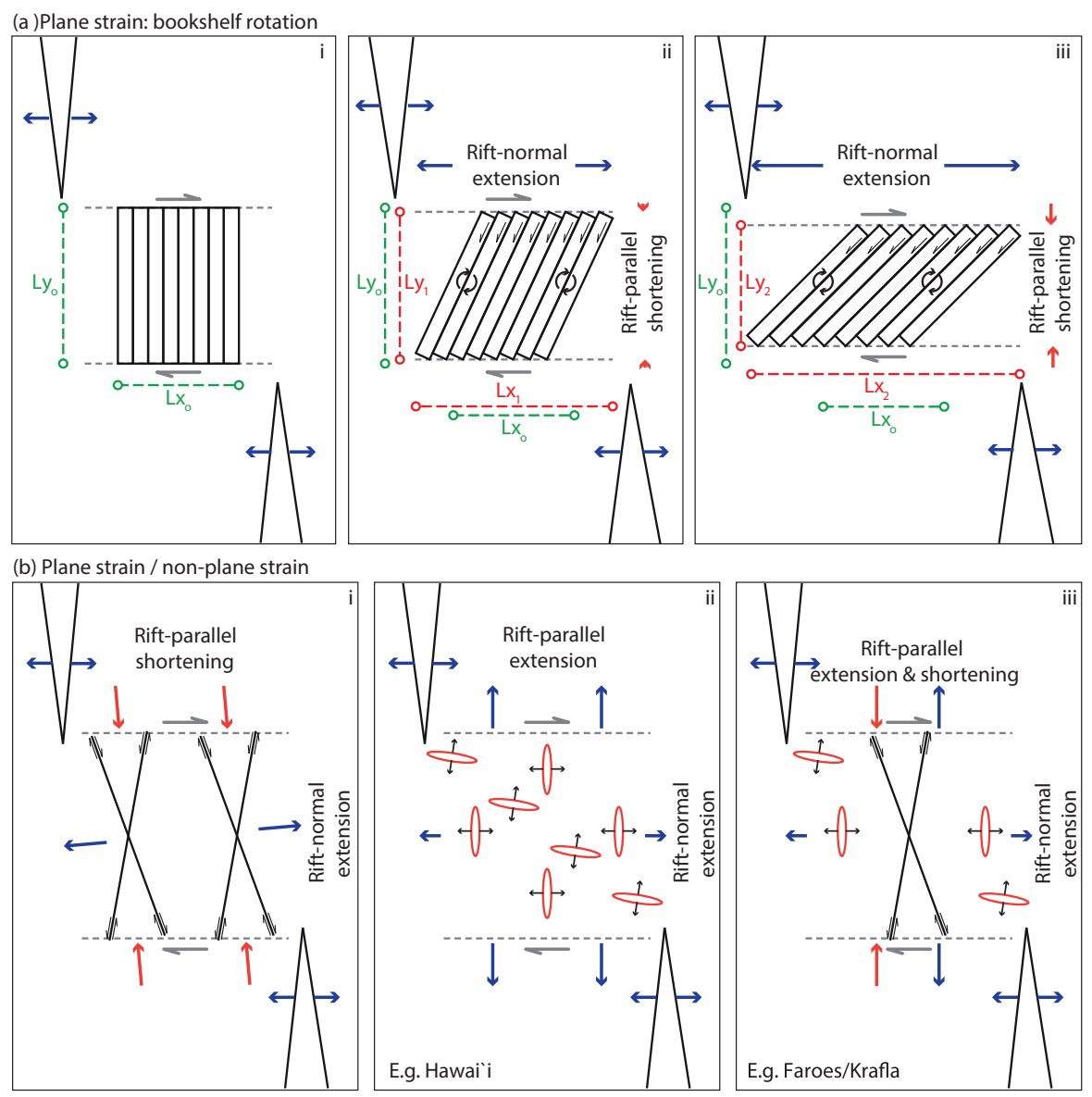

Figure 10. Horizontal plane 2-D conceptual models for inter-fault and inter-rift relay rotation. (a) Bookshelf rotation model showing (iiii) progressive rotation leading to rift-normal extension and rift-parallel shortening. (b) Schematic models for structures observed in the study areas presented here: (i) conjugate extensional shear faults, (ii) extension fractures, and (iii) a combination of extension fractures and conjugate extensional shear faults. If faults develop throw, as in the Krafla example, the system becomes non-plane strain. Models are not to scale.

tics similar to those observed in the Koa'e and Krafla study sites, including (1) segmented bounding faults, (2) progressive development of obliquely oriented ancillary fault structures internal to the relay zone that accommodate non-coaxial strains, and (3) rift-zone-parallel connecting faults.

Evidence for vertical axis rotations on the rift zone scale (i.e. tens to hundreds of kilometres) has previously been attributed to bookshelf-type faulting models (e.g. Green et al., 2014; Fig. 10a). In such models, a vertical axis rotation can contribute to rift-zone-normal extension. In horizontal axis rotations, via bookshelf faulting, a shear couple in the vertical plane represents a horizontal extension and a vertical shortening (i.e. crustal thinning). In vertical axis rotation, shortening would require a horizontal material thinning along the rift zone: in plane strain, this would not require vertical crustal thinning. Vertical axis rotations by this mechanism, with a shear couple in the horizontal plane requires horizontal shortening (Fig. 10). For a rigid block model, the rotation has the effect of causing a material thickening orthogonal to the rift zone (e.g. Fig. 1e). Figure 1e shows that this rotation also results in material extension parallel to the rift axis, allowing addition of new material as a volume increase; during nonrigid body rotations (e.g. Fig. 10), second-order faults may act to facilitate the coupled components of rift-zone-normal extension and rift-zone-parallel shortening (e.g. Fig. 10b). For faults in the Krafla study area, we infer that rift-zoneparallel shortening is counteracted, contemporaneously, by the extensional component of obliquely oriented extensional shear faults and rift-normal-striking extension fractures at the free surface (e.g. Fig. 10b(iii)). At depth, this volume increase could occur as veins and/or dikes.

\subsection{A vertical axis rotation model for rift basin segmentation in the NE Atlantic}

Structures in the Faroe Islands and east Greenland share a common geometric, kinematic, and temporal evolution (Figs. 8 and 9), formed before and during continental break- 

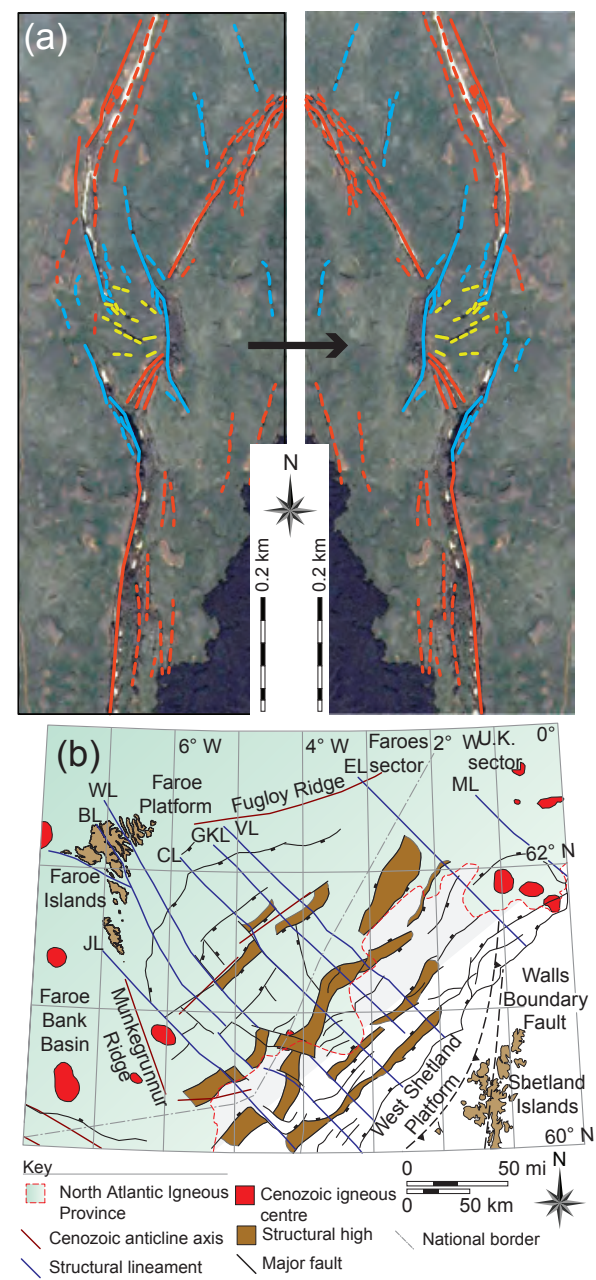

(c)
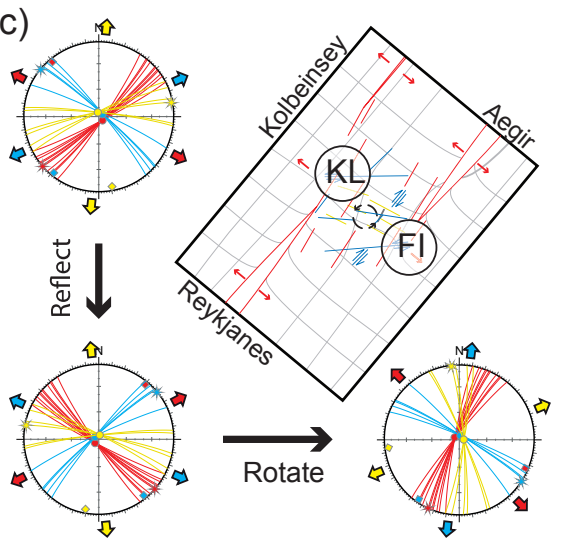

Figure 11. (a) Reflection of left-stepping Krafla faults to a rightstepping NE Atlantic rift configuration. (b) Map of the European margin of the NE Atlantic showing the broad NE-SW basin trend. JL: Judd Lineament; CL: Clare Lineament; GKL: Grimur Kamban Lineament; VL: Victory Lineament; EL: Erlend Lineament; ML: Møre Lineament; BL: Brynhild Lineament; WL: Westray Lineament. (c) Krafla faults are rotated into the orientation of the Atlantic European margin basin system and compared with the ReykjanesÆgir system. up. Structures accommodate extensional strains at a range of angles relative to the regional extension vector (NW-SE) associated with a vertical axis rotation in the maximum horizontal stress (Figs. 8 and 9). Here we apply a geometric and kinematic comparison between the observed structures on the Atlantic margins and smaller-scale structures that evolved in regions of extension deficit and rotation in the Koa'e and Krafla fault systems to consider, by analogy, whether vertical axis rotation during extension presents a viable model for strain evolution on a scale of tens of kilometres. We focus on the Krafla system, as the extensional strain accommodated there has produced surface breaching structures that are closely comparable to the Atlantic margin.

To make the comparison of relative fault orientations and kinematics between the Krafla analogue and the NE Atlantic margins, we have rotated the Krafla rift datasets into the orientation and overlap configuration of the Atlantic European margin basin systems, i.e. a NE-SW-trending, rightstepping rift. Thus, a right-stepping mirror image of the leftstepping Krafla rift is used (Fig. 12a) and compared with the Reykjanes-\#gir system, with the rift-parallel-striking faults rotated into parallelism with those of the NE Atlantic margin (Fig. 12b, c). Here data rotation is undertaken in two ways for comparison: (1) by rotating the measured planar data for the Krafla system into an orientation that matches the strike of basin- and sub-basin faults along the Faroe-Shetland Basin and (2) by rotating the measured planar data for the Krafla system so that the average strike of the rift-parallel structures matches the measured strike of rift-parallel structures in the Faroe Islands and east Greenland. The two styles of rotation result in a difference in second-order fault orientation of $30^{\circ}$, which is significant for data comparison. However, both types of rotation lead to the second-order data becoming parallel with either ENE- or ESE-striking structures mapped in the Faroe Islands and Kangerlussuaq (Fig. 12a-d). All of the study areas show kinematically near-identical fault sets, with a $20-28^{\circ}$ spread in extension directions across datasets. Removing one or the other of the reoriented Krafla sets reduces the spread to $12-20^{\circ}$. Importantly, each dataset comprises rift-parallel-striking faults that open normal to the rift axis (red in Fig. 12e), rift-oblique-striking structures that accommodate extension oblique to the rift zone (blue in Fig. 12e), and rift-normal-striking structures that accommodate extension parallel to the rift zone (yellow in Fig. 12e). Rift-zoneparallel extension in the Krafla study area is accommodated by extension-mode fractures at the surface that strike orthogonal to the bounding rift faults. Equivalent subsurface structural sets exposed in the Faroe Islands and in east Greenland are normal faults and dikes. Notably, evidence for this style of inter-rift system architecture has also been noted in the East African Rift, where, in younger portions of the rift, obliquely oriented dikes accommodate rift-zone-parallel extension in the intervening relay zone between rift segments (scale of tens of kilometres; e.g. Muirhead et al., 2015). 


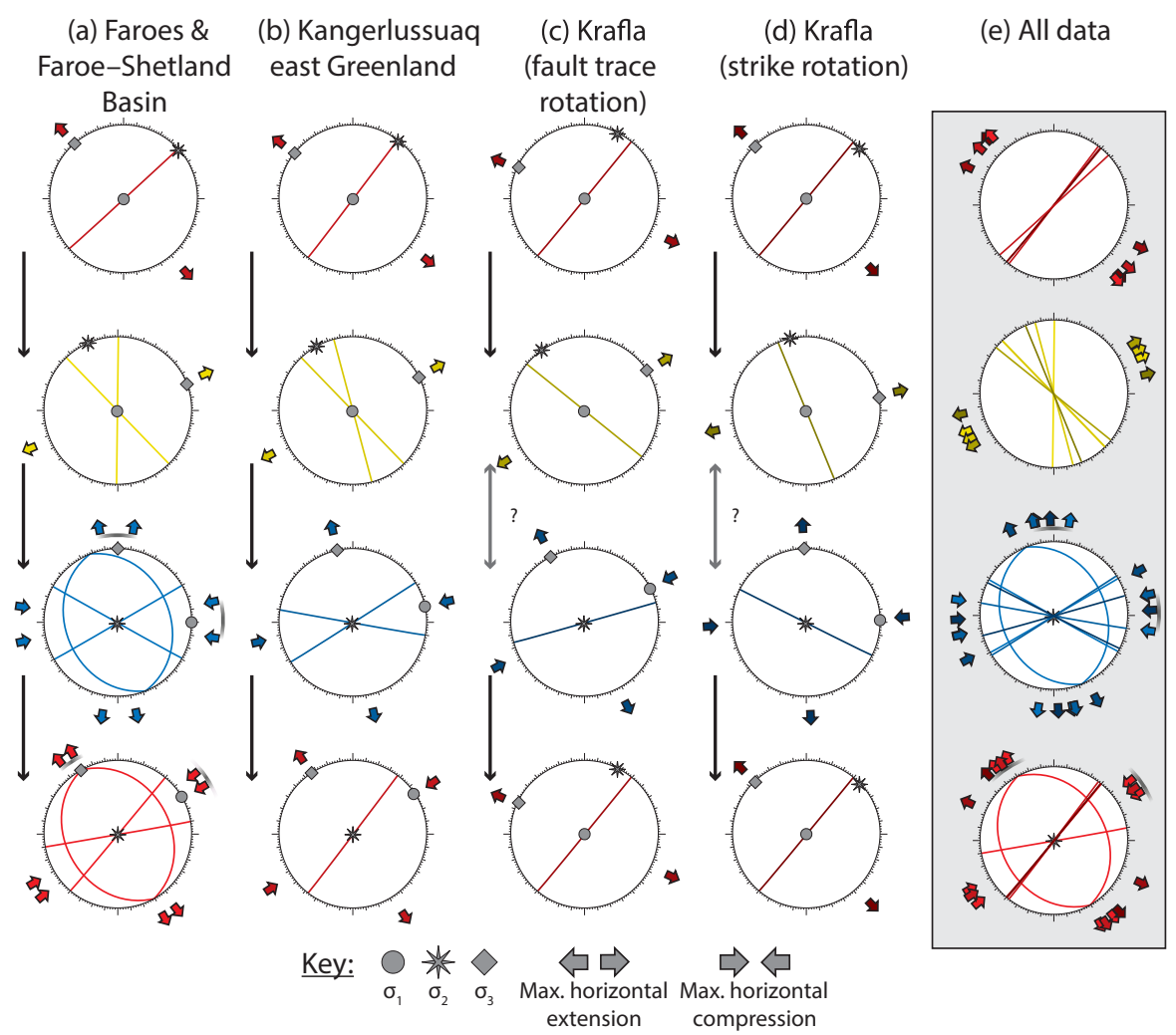

Figure 12. Comparison of averaged structural orientations and kinematics for the Faroe Islands (a) and east Greenland (b). (c) Krafla data are reflected and rotated so that the surface traces match the NE Atlantic basin system. (d) Krafla data are reflected and rotated so that the measured planar data match the measured data from the NE Atlantic basin system. (e) Combined summary of orientations and kinematics from each study area.

Rift-parallel-striking fault sets along both margins represent the first and final structural set. Timing relationships of fault sets on the Faroe Islands and in east Greenland imply a progressive vertical axis stress rotation at the regional scale, which is consistent with models that predict break-up involved a series of initially underlapping rift systems during rift propagation (Ellis and Stoker, 2014) (Fig. 7b-c). Although the history of fault sets in the Krafla relay zone is less clear, the interpreted pattern fits well with the strains observed on a larger scale along the NE Atlantic margins (Fig. 12). We therefore propose that a vertical axis rotation model (associated with heave gradients) can account for margin-normal-striking normal faults, dikes, and lineaments in segmented rift systems and presents a viable alternative to a polyphase extension and reorganization, or strikeslip - transfer - models, that has been applied previously (e.g. Ellis et al., 2009). Our new model, however, cannot and should not be applied along the entire length of the European margin in a simple way. Along this margin segmentation styles vary considerably, from large-scale, localized transform faults, e.g. the Jan Mayen Fracture Zone, or the Senja Fracture Zone in the Norwegian-Greenland seas (e.g. Skogseid and Eldholm, 1987; Gernigon et al., 2009), to distributed, discontinuous continental-style accommodation zones along the Møre-Faroes-Rockall portion of the margin.

Variations in the along-strike segmentation and scaling of fault populations have been well-documented in both continental rift (e.g. Hayward and Ebinger, 1996; Scholz and Contreras, 1998; Faulds and Varga, 1998) and oceanic fault populations (e.g. Carbotte and Macdonald, 1994; Macdonald, 1998). Variations have previously been attributed to changes in crustal thickness, strain rate (i.e. heat diffusion and/or magma supply), segment configuration, and the presence of pre-existing "weak" structures (e.g. Cowie, 1998; Corti et al., 2003; Tentler and Acocella, 2010; Gerya, 2012, 2013). Scaled-analogue models of normal fault populations have demonstrated that increases in effective elastic layer thickness result in a dominance of small and widely distributed faults (Ackermann et al., 1997, 2001). With increasing total extension, these authors noted that faults increased in number and length, producing a close and regularly spaced network. More recent scaled-analogue modelling of ridgetransform fault configurations also suggests that fault style and scaling is a function of strain rate and crustal thickness, with a relatively thick lithosphere producing oblique zones of rifting and a relatively thin lithosphere resulting in the 
development of transform faults that link the offset accreting segments (Gerya, 2012, 2013). With estimated crustal thicknesses in the NE Atlantic varying from $\sim 3-10 \mathrm{~km}$ in the Norwegian-Greenland seas to $\sim 10-35 \mathrm{~km}$ in the Rockall Basin and the Greenland-Iceland-Faroes Ridge (Smallwood and White, 2002; Gernigon et al., 2009), variations in axis-parallel segmentation patterns are to be expected (e.g. Hayward and Ebinger, 1996). Localized and large-scale fracture zones along the NE Atlantic margins only occur where crustal thicknesses fall below $10 \mathrm{~km}$; elsewhere we find thick crust and distributed fault systems that are dominated by accommodation zone-style stress transfer, rather than regionalscale strike-slip faults. The protracted extensional history of the region and superposition of NE Atlantic rifting on Paleozoic rift systems, themselves influenced by Caledonian and/or older fabrics, mean that pre-existing structural weaknesses are likely to be widespread along the margin (e.g. Doré et al., 1999), and the style of segmentation appears to vary considerably. Although the controls on segmentation style in the NE Atlantic are beyond the scope of this study to investigate, it is nevertheless important to consider the potential role of factors such as pre-existing structures, strain rate, or crustal thickness when applying any single model to the entire margin.

\section{Conclusions}

Discontinuous normal faults in the Koa'e and Krafla fault systems accommodate regional horizontal extensional strains via a combination of fault throw and heave on first-order rift faults. Obliquely oriented second-order deformation is driven by extension gradients and vertical axis block rotation within the intervening relay zones.

Second-order faults and fractures serve to accommodate components of the regional extension and, variably, a component of shortening and extension in a direction parallel toand oblique to the rift zone.

Fault population heterogeneity within relay zones is attributed to locally non-coaxial stress states associated with mechanical interaction and resulting fault displacement gradients, rather than regional-scale polyphase tectonic episodes or changes in the remote stress field.

Relay zones are considered to occur across most scales of segmented extensional systems; thus, we infer that vertical axis block rotations and the associated local deformation, which accommodate deficits in fault heave, occur within the same range of scales. The distribution of second-order structures is controlled by the scale of segmentation.

A displacement deficit-rotation model is applied to the NE Atlantic margins, in which second-order fault sets locally accommodate margin-parallel extension and shortening during vertical axis rotation. We show that this is a viable alternative model to explain the upper crustal geometry, kinematics, and timing of structures versus existing strike-slip (transfer) segmentation models for the case study presented, but urge caution in applying the model along the length of a given system.

Data availability. Raw data for study sites on the Faroe Islands are published in Walker (2010) and Walker et al. (2011). Field locations may be found in Figs. 3, 5, 8, and 9. Raw data are not currently available due to ongoing data analysis but will be made available to the broader community in due course. For specific requests in the meantime, please contact A. Bubeck (ab753@le.ac.uk).

Author contributions. Data from Hawai' $i$ and Iceland were collected by AB. Data from the Faroe Islands and Greenland were collected by RW. RH and JI provided valuable discussion. CM and DH assisted with data collection and contributed to the discussion. AB prepared the paper with contributions from all co-authors.

Competing interests. The authors declare that they have no conflict of interest.

Acknowledgements. This study was funded via Richard J. Walker's University of Leicester start-up fund, as part of Alodie Bubeck's $\mathrm{PhD}$ project. Observations crucial to this study were made during Richard J. Walker's $\mathrm{PhD}$ research, which was funded by Statoil (UK) Ltd. Thanks to Pierpaolo Guarnieri for making it possible to collect data in east Greenland, and thank you to the Føroya Dàtusavn for access to Faroes aerial imagery. We thank Richard England for discussions during manuscript preparation. We thank reviewers Atle Rotevatn and Lucia Perez-Diaz for constructive feedback, which greatly improved the clarity of this manuscript. We gratefully acknowledge Don Swanson (HVO) and Mike Poland (formerly HVO) for their help and advice during fieldwork planning and data collection, and we thank the National Park Service for granting a research permit to conduct fieldwork in the Koa'e fault system. Aerial lidar datasets were provided by the OpenTopography Facility with support from the National Science Foundation under NSF award nos. 1226353 \& 1225810 (not related to this study).

Edited by: Gwenn Peron-Pinvidic

Reviewed by: Atle Rotevatn and Lucia Perez-Diaz

\section{References}

Ackermann, R. V. and Schlische, R. W.: Anticlustering of small normal faults around larger faults, Geology, 25, 1127-1130, 1997.

Ackermann, R. V., Schlische, R. W., and Withjack, M. O.: The geometric and statistical evolution of normal fault systems: an experimental study of the effects of mechanical layer thickness on scaling laws, J. Struct. Geol., 23, 1803-1819, 2001.

Acocella, V., Morvillo, P., and Funiciello, R.: What controls relay ramps and transfer faults within rift zones? In- 
sights from analogue models, J. Struct. Geol., 27, 397-408, https://doi.org/10.1016/j.jsg.2004.11.006, 2005.

Carbotte, S. M. and Macdonald, K. C.: Comparison of seafloor tectonic fabric at intermediate, fast, and super fast spreading ridges: Influence of spreading rate, plate motions, and ridge segmentation on fault patterns, J. Geophys. Res.-Solid Earth, 99, 1360913631, https://doi.org/10.1029/93jb02971, 1994.

Cartwright, J., Mansfield, C. S., and Trudgill, B.: The growth of normal faults by segment linkage, in: Modern Developments in Structural Interpretation, Validation and Modelling, edited by: Buchanan, P. G. and Nieuland, D. A., Vol. Geological Society Special Publication No. 99, London, UK, The Geological Society, 1996.

Casey, M., Ebinger, C., Keir, D., Gloaguen, R., and Mohamed, F. (Eds.): Strain accommodation in transitional rifts: extension by magma intrusion and faulting in Ethopian rift magmatic segments. Geological Society, London, Special Publications, Vol. 259, The Geological Society of London, 2006.

Childs, C., Watterson, J., and Walsh, J. J.: Fault overlap within developing normal fault systems, J. Geol. Soc., London, 152, 535549, 1995.

Childs, C., Holdsworth, R. E., Jackson, C. A. L., Manzocchi, T., Walsh, J. J., and Yielding, G.: Introduction to the geometry and growth of normal faults. Geological Society, London, Special Publications, 439, 1-9, 5 September 2017, available at: https://doi.org/10.1144/SP439.24, 2017.

Corti, G., Bonini, M., Conticelli, S., Innocenti, F., Manetti, P., and Sokoutis, D.: Analogue modelling of continental extension: a review focused on the relations between the patterns of deformation and the presence of magma, Earth-Sci. Rev., 63, 169-247, https://doi.org/10.1016/s0012-8252(03)00035-7, 2003.

Cowie, P.: Normal fault growth in three-dimensions in continental and oceanic crust, in: Faulting and magmatism at mid-ocean ridges, edited by: Buck, W. R., Delaney, P. T., Karson, J. A., and Lagabrielle, Y., Washington, D.C. American Geophysical Union, https://doi.org/10.1029/GM106p0027, 1998.

Cowie, P. A. and Scholz, C. H.: Physical explanation for the displacement-length relationship of faults using a post-yield fracture mechanics model, J. Struct. Geol., 14, 1133-1148, https://doi.org/10.1016/0191-8141(92)90065-5, 1992.

Crider, J. G. and Pollard, D. D.: Fault linkage: Three-dimensional mechanical interaction between echelon normal faults, J. Geophys. Res., 103, 24373, https://doi.org/10.1029/98jb01353, 1998.

Dauteuil, O., Angelier, J., Bergerat, F., Verrier, S., and Villemin, T.: Deformation partitioning inside a fissure swarm of the northern icelandic rift, J. Struct. Geol., 23, 1359-1372, 2001.

Doré, A. G., Lundin, E. R., Birkeland, O., Eliassen, P. E., and Jensen, L. N.: The NE Atlantic margin; implications of late Mesozoic and Cenozoic events for hydrocarbon prospectivity, Petrol. Geosci., 3, 117-131, https://doi.org/10.1144/petgeo.3.2.117, 1997.

Doré, A. G., Lundin, E. R., Jensen, L. N., Birkeland, Ø., Eliassen, P. E., and Fichler, C.: Principal tectonic events in the evolution of the northwest European Atlantic margin, in: Geological society, London, petroleum geology conference series, 5, 41-61, Geological Society of London, 1999.

Doré, A. G., Lundin, E. R., Kusznir, N. J., and Pascal, C.: Potential mechanisms for the genesis of Cenozoic domal structures on the NE Atlantic margin: pros, cons and some new ideas. Geological Society, London, Special Publications, 306, 1-26, https://doi.org/10.1144/sp306.1, 2008.

Dzurisin, D., Koyanagi, R. Y., and English, T. T.: Magma supply and storage at Kiluea Volcano, Hawaii, 1956-1983, J. Volcanol. Geotherm. Res., 21, 177-206, 1984.

Ellis, D. and Stoker, M. S. (Eds.): The Faroe-Shetland Basin: a regional perspective from the Paleocene to the present day and its relationship to the opening of the North Atlantic Ocean, in: Hydrocarbon exploration to exploitation West of Shetlands, edited by: Cannon, S. J. C. and Ellis, D., Geological Society, London, Special Publications (Vol. 397), The Geological Society of London, 2014.

Ellis, D., Passey, S. R., Jolley, D. W., and Bell, B. R.: Transfer zones: the application of new geological information from the Faroe Islands applied to the offshore exploration of intra and sub-basalt strata, Paper presented at the Faroe Islands exploration conference: proceedings of the 2nd conference, Torshavn, Faroe Islands, 2009.

Faulds, J. E. and Varga, R. J.: The role of accommodation zones and transfer zones in the regional segmentation of extended terranes, in: Accommodation zones and transfer zones: the regional segmentation of the Basin and Range Province, edited by: Faulds, J. E. and Stewart, J. H., Boulder, Colorado (Vol. 323): Geological Society of America Special Paper, 1998.

Ferrill, D. A. and Morris, A. P.: Displacement gradient and deformation in normal fault systems, J. Struct. Geol., 23, 619-638, 2001.

Ferrill, D. A., Stamatakos, J. A., and Sims, D.: Normal fault corrugation: implications for growth and seismictiy of active normal faults, J. Struct. Geol., 21, 1027-1038, 1999.

Fossen, H. and Rotevatn, A.: Fault linkage and relay structures in extensional settings - A review, Earth-Sci. Rev., 154, 14-28, https://doi.org/10.1016/j.earscirev.2015.11.014, 2016.

Gaina, C., Gernigon, L., and Ball, P.: Palaeocene-Recent plate boundaries in the NE Atlantic and the formation of the Jan Mayen microcontinent, J. Geol. Soc., 166, 601-616, https://doi.org/10.1144/0016-76492008-112, 2009.

Gawthorpe, R. L. and Hurst, J. M.: Transfer zones in extensional basins: their structural style and influence on drainage development and stratigraphy, J. Geol. Soc., 150, 1137-1152, https://doi.org/10.1144/gsjgs.150.6.1137, 1993.

Gernigon, L., Olesen, O., Ebbing, J., Wienecke, S., Gaina, C., Mogaard, J. O., Sand, M., and Myklebust, R.: Geophysical insights and early spreading history in the vicinity of the Jan Mayen Fracture Zone, Norwegian-Greenland Sea, Tectonophysics, 468, 185-205, 2009.

Gernigon, L., Gaina, C., Olesen, O., Ball, P. J., Péron-Pinvidic, G., and Yamasaki, T.: The Norway Basin revisited: From continental breakup to spreading ridge extinction, Mar. Petrol. Geol., 35, 119, https://doi.org/10.1016/j.marpetgeo.2012.02.015, 2012.

Gerya, T.: Origin and models of oceanic transform faults. Tectonophysics, 522-523, 34-54, https://doi.org/10.1016/j.tecto.2011.07.006, 2012.

Gerya, T. V.: Initiation of transform faults at rifted continental margins: 3D petrological-thermomechanical modeling and comparison to the Woodlark Basin, Petrology, 21, 550-560, https://doi.org/10.1134/s0869591113060039, 2013. 
Grant, J. V. and Kattenhorn, S. A.: Evolution of vertical faults at an extensional plate boundary, southwest Iceland, J. Struct. Geol., 26, 537-557, https://doi.org/10.1016/j.jsg.2003.07.003, 2004.

Green, R. G., White, R. S., and Greenfield, T.: Motion in the north Iceland volcanic rift zone accommodated by bookshelf faulting, Nature Geosci., 7, 29-33, https://doi.org/10.1038/ngeo2012, 2014.

Guarnieri, P.: Pre-break-up palaeostress state along the East Greenland margin, J. Geol. Soc., 172, 727-739, 2015.

Gupta, A. and Scholz, C. H.: A model of normal fault interaction based on observations and theory, J. Struct. Geol., 22, 865-879, 2000.

Hayward, N. J. and Ebinger, C. J.: Variations in the alongaxis segmentation of the Afar Rift system, Tectonics, 15, 244, https://doi.org/10.1029/95tc02292, 1996.

Henstra, G. A., Rotevatn, A., Gawthorpe, R. L., and Ravnås, R.: Evolution of a major segmented normal fault during multiphase rifting: The origin of plan-view zigzag geometry, J. Struct. Geol., 74, 45-63, 2015.

Holland, M., Urai, J. L., and Martel, S. J.: The internal structure of fault zones in basaltic sequences, Earth Planet. Sci. Lett., 248, 301-315, 2006.

Holm, P. M., Heaman, L. M., and Pedersen, L. E.: Baddeleyite and zircon $\mathrm{U}-\mathrm{Pb}$ ages from the Kærven area, Kangerlussuaq: Implications for the timing of Paleogene continental breakup in the North Atlantic, Lithos, 92, 238-250, https://doi.org/10.1016/j.lithos.2006.03.035, 2006.

Holwell, D. A., Abraham-James, T., Keays, R. R., and Boyce, A. J.: The nature and genesis of marginal $\mathrm{Cu}-\mathrm{PGE}-\mathrm{Au}$ sulphide mineralisation in Paleogene Macrodykes of the Kangerlussuaq region, East Greenland, Mineralium Deposita, 47, 3-21, https://doi.org/10.1007/s00126-010-0325-4, 2012.

Hus, R., De Batist, M., Klerkx, J., and Matton, C.: Fault linkage in continental rifts: structure and evolution of a large relay ramp in Zavarotny; Lake Baikal (Russia), J. Struct. Geol., 28, 1338-1351, https://doi.org/10.1016/j.jsg.2006.03.031, 2006.

Irvine, T. N., Andersen, J. C. Ø., and Brooks, C. K.: Geological Society of America Bulletin, $110, \quad 1398, \quad$ https://doi.org/10.1130/00167606(1998)110<1398:ibabwb>2.3.co;2, 1998.

Kattenhorn, S. A., Aydin, A., and Pollard, D. D.: Joints at high angles to normal fault strike: an explanation using 3-D numerical models of fault-perturbed stress fields, J. Struct. Geol., 22, 1-23, 2000.

Koehn, D., Aanyu, K., Haines, S., and Sachau, T.: Rift nucleation, rift propagation and the creation of basement microplates within active rifts, Tectonophysics, 458, 105-116, https://doi.org/10.1016/j.tecto.2007.10.003, 2008.

Koehn, D., Lindenfeld, M., Rümpker, G., Aanyu, K., Haines, S., Passchier, C. W., and Sachau, T.: Active transsection faults in rift transfer zones: evidence for complex stress fields and implications for crustal fragmentation processes in the western branch of the East African Rift, Int. J. Earth Sci., 99, 1633-1642, https://doi.org/10.1007/s00531-010-0525-2, 2010.

Lambiase, J. J. and Bosworth, W.: Structural controls on sedimentation in continental rifts, in: Hydrocarbon habitat in rift basins, edited by: Lambiase, J. J., Vol. Geological Society Special Publications No. 80, London, UK: The Geological Society, 1995.
Lin, G. and Okubo, P. G.: A large refined catalog of earthquake relocations and focal mechanisms for the Island of Hawai' $i$ and its seismotectonic implications, J. Geophys. Res.-Solid Earth, 121, 5031-5048, https://doi.org/10.1002/2016jb013042, 2016.

Long, J. J. and Imber, J.: Geometrically coherent continuous deformation in the volume surrounding a seismically imaged normal fault-array, J. Struct. Geol., 32, 222-234, https://doi.org/10.1016/j.jsg.2009.11.009, 2010.

Long, J. J. and Imber, J.: Geological controls on fault relay zone scaling, J. Struct. Geol., 33, 1790-1800, https://doi.org/10.1016/j.jsg.2011.09.011, 2011.

Macdonald, K. C.: Linkages between faulting, volcanism, hydrothermal activity and segmentation on fast spreading centers, in: Faulting and magmatism at mid-ocean ridges, edited by: Buck, W. R., Delaney, P. T., Karson, J. A., Lagabrielle, Y., Washington, D.C.: American Geophysical Union, https://doi.org/10.1029/GM106p0027, 1998.

Macdonald, K. C., Fox, P. J., Alexander, R. T., Pockalny, R., and Gente, P., Volcanic growth faults and the origin of Pacific abyssal hills, Nature, 380, 125-129, 1996.

Maerten, L., Gillespie, P., and Pollard, D. D.: Effects of local stress perturbation on secondary fault development, J. Struct. Geol., 24, 145-153, 2002.

Mandl, G.: Tectonic deformation by rotating parallel faults: the "bookshelf" mechanism, Tectonophysics, 141, 277-316, 1987.

Manzocchi, T., Childs, C., and Walsh, J. J.: Faults and fault properties in hydrocarbon flow models, Geofluids, 10, 94-113, https://doi.org/10.1111/j.1468-8123.2010.00283.x, 2010.

Martel, S. J. and Langley, J. S.: Propagation of normal faults to the surface in basalt, Koae fault system, Hawaii, J. Struct. Geol., 28, 2123-2143, https://doi.org/10.1016/j.jsg.2005.12.004, 2006.

Morley, C. K., Nelson, R. A., Patton, T. I., and Munn, S. G.: Transfer zones in the East Africa Rift System and their relevance to hydrocarbon exploration in rifts, The American Association of Petroleum Geologists Bulletin, 74, 1234-1253, 1990.

Morris, A. P., McGinnis, R. N., and Ferrill, D. A.: Fault displacement gradients on normal faults and associated deformation, AAPG Bulletin, 98, 1161-1184, https://doi.org/10.1306/10311312204, 2014.

Muirhead, J. D., Kattenhorn, S. A., and Le Corvec, N.: Varying styles of magmatic strain accommodation across the East African Rift, Geochem. Geophy. Geosy., 16, 2775-2795, https://doi.org/10.1002/2015gc005918, 2015.

Passey, S. R. and Jolley, D. W.: A revised lithostratigraphic nomenclature for the Palaeogene Faroe Islands Basalt Group, NE Atlantic Ocean, Earth and Environmental Science Transactions of the Royal Society of Edinburgh, 99, 127, https://doi.org/10.1017/s1755691009008044, 2009.

Peacock, D. C. P.: Propagation, interaction and linkage in normal fault systems, Earth Sci. Rev., 58, 121-142, 2002.

Peacock, D. C. P.: Scaling of transfer zones in the British Isles, J. Struct. Geol., 25, 1561-1567, https://doi.org/10.1016/s01918141(03)00008-7, 2003.

Peacock, D. C. P. and Sanderson, D. J.: Displacements, segment linkage and relay ramps in normal fault zones, J. Struct. Geol., 13, 721-733, 1991.

Peacock, D. C. P. and Sanderson, D. J.: Geometry and Development of Relay Ramps in Normal Fault Systems, AAPG Bul- 
letin, 78, 147-165, https://doi.org/10.1306/bdff9046-1718-11d78645000102c1865d, 1994.

Peacock, D. C. P., Price, S. P., Whitham, A. G., and Pickles, C. S.: The World's biggest relay ramp: Hold With Hope, NE Greenland, J. Struct. Geol., 22, 843-850, 2000.

Poland, M. P., Miklius, A., Sutton, A. J., and Thornber, C. R.: A mantle-driven surge in magma supply to Kilauea Volcano during 2003-2007, Nature Geoscience, 5, 295-300, https://doi.org/10.1038/ngeo1426, 2012.

Roberts, N. M. W. and Walker, R. J.: U-Pb geochronology of calcite-mineralized faults: Absolute timing of rift-related fault events on the northeast Atlantic margin, Geology, 44, 531-534, https://doi.org/10.1130/g37868.1, 2016.

Rotevatn, A., Fossen, H., Hesthammer, J., Aas, T. E., and Howell, J. A.: Are relay ramps conduits for fluid flow? Structural analysis of a relay ramp in Arches National Park, Utah, in: Lonergan, L., Jolley, R. J. H., Rawnsley, K., and Sanderson, D. J., Fractured Reservoirs. Geological Society London Special Publication 270, 55-71, The Geological Society, London, 2007.

Rumph, B., Reaves, C. M., Orange, V. G., and Robinson, D. L.: Structuring and transfer zones in the Faeroe Basin in a regional tectonic context, Petroleum Geology Conference Series, 4, 999 1009, 1993.

Sachau, T., Koehn, D., Stamps, D. S., and Lindenfeld, M.: Fault kinematics and stress fields in the Rwenzori Mountains, Uganda, Int. J. Earth Sci., 105, 1729-1740, https://doi.org/10.1007/s00531-015-1162-6, 2016.

Scholz, C. H. and Contreras, J. C.: Mechanics of continental rift architecture, Geology, 26, 967-970, 1998.

Seebeck, H., Nicol, A., Walsh, J. J., Childs, C., Beetham, R. D., and Pettinga, J.: Fluid flow in fault zones from an active rift, J. Struct. Geol., 62, 52-64, https://doi.org/10.1016/j.jsg.2014.01.008, 2014.

Segall, P. and Pollard, D. D.: Mechanics of Discontinuous Faults, J. Geophys. Res., 85, 4337-4350, 1980.

Sempere, J. C. and Macdonald, K. C.: Overlapping spreading centers: implications from crack growth simulation by the displacement discontinuity method, Tectonics, 5, 151-163, 1986.

Sharp, I. R., Gawthorpe, R. L., Underhill, J. R., and Gupta, S.: Fault-propagation folding in extensional settings: Examples of structural style and synrift sedimentary response from the Suez rift, Sinai, Egypt. Geological Society of America Bulletin, 112, 1877-1899, https://doi.org/10.1130/00167606(2000)112<1877:FPFIES>2.0.CO;2, 2000.

Skogseid, J. and Eldholm, O.: Early Cenozoic crust at the Norwegian continental margin and the conjugate Jan Mayen Ridge, J. Geophys. Res.-Solid Earth, 92, 11471-11491, https://doi.org/10.1029/JB092iB11p11471, 1987.
Smallwood, J. R. and White, R. S.: Ridge-plume interaction in the North Atlantic and its influence on continental breakup and seafloor spreading, in: The North Atlantic Igneous Province: Stratigraphy, Tectonic, Volcanic and Magmatic Processes, edited by: Jolley, D. W. and Bell, B. R., Vol. 197, 15-37, London, UK: The Geological Society of London, 2002.

Swanson, D. A., Fiske, R. S., Thornber, C. R., and Poland, M. P.: Dikes in the Koa'e fault system, and the Koa'e-east rift zone structural grain at Kîlauea Volcano, Hawai' $\mathrm{i}$ : Geological Society of America Special Paper, in press, 2017.

Tegner, C., Duncan, R. A., Bernstein, S., Brooks, C. K., Bird, D. K., and Storey, M.: 40Ar-39Ar geochronology of Tertiary mafic intrusions along the East Greenland rifted margin: Relation to flood basalts and the Iceland hotspot track, Earth Planet. Sci. Lett., 156, 75-88, 1998.

Tentler, T.: Propagation of brittle failure triggered by magma in Iceland, Tectonophysics, 406, 17-38, 2005.

Tentler, T. and Acocella, V.: How does the initial configuration of oceanic ridge segments affect their interaction? Insights from analogue models, J. Geophys. Res., 115, https://doi.org/10.1029/2008jb006269, 2010.

Trudgill, B. and Cartwright, J.: Relay-ramp forms and normal fault linkages. Canyonlands National Park, Utah, Geological Society of America Bulletin, 106, 1143-1157, 1994.

Walker, R. J.: The Structural Evolution of the Faroe Islands, NE Atlantic Margin, Doctor of Philosophy, Durham Univerisity, 2010.

Walker, R. J., Holdsworth, R. E., Imber, J., and Ellis, D.: Onshore evidence for progressive changes in rifting directions during continental break-up in the NE Atlantic, J. Geol. Soc., 168, 27-48, https://doi.org/10.1144/0016-76492010-021, 2011.

Walsh, J. J., Bailey, W. R., Childs, C., Nicol, A., and Bonson, C. G.: Formation of segmented normal faults: a 3D perspective, J. Struct. Geol., 25, 1251-1262, 2003.

Willemse, E. J. M., Pollard, D. D., and Aydin, A.: Threedimensional analyses of slip distributions on normal fault arrays with consequences for fault scaling, J. Struct. Geol., 18, 295309, 1996.

Wotzlaw, J. F., Bindeman, I. N., Schaltegger, U., Brooks, C. K., and Naslund, R. H.: High-resolution insights into episodes of crystallization, hydrothermal alteration and remelting in the Skaergaard intrusive complex, Earth Planet. Sci. Lett., 355-356, 199-212, https://doi.org/10.1016/j.eps1.2012.08.043, 2012.

Wright, T. L. and Klein, F. W.: Deep magma transport at Kilauea volcano, Hawaii, Lithos, 87, 50-79, https://doi.org/10.1016/j.lithos.2005.05.004, 2006. 